The Free Internet Journal

for Organic Chemistry
Review

Arkivoc 2020, part i, 180-218

Organic Chemistry

\title{
Antiviral activity of thiadiazoles, oxadiazoles, triazoles and thiazoles
}

\author{
Samar S. Tawfik, ${ }^{a}$ Mengyao Liu, ${ }^{b}$ and Abdelbasset A. Farahat*a,b \\ ${ }^{a}$ Department of Pharmaceutical Organic Chemistry, Faculty of Pharmacy, University of Mansoura, \\ Mansoura 35516, Egypt \\ ${ }^{b}$ Master of Pharmaceutical Sciences Program, California Northstate University, 9700 W Taron Dr., \\ Elk Grove, CA 95757, U.S.A. \\ Email: Abdelbasset.farahat@cnsu.edu
}

Received 07-21-2020

Accepted 08-12-2020

Published on line $08-18-2020$

\section{Abstract}

Drugs containing the heterocyclic five-membered thiadiazoles and isosteres possess a wide range of biological activities, including but not limited to, antiviral, antifungal, antihistamine, anticancer. In this study, we list the agents containing thiadiazoles and isosteres which are reported to have antiviral activity. We believe that this compilation will be a useful resource for researchers working in the field of antiviral agents.

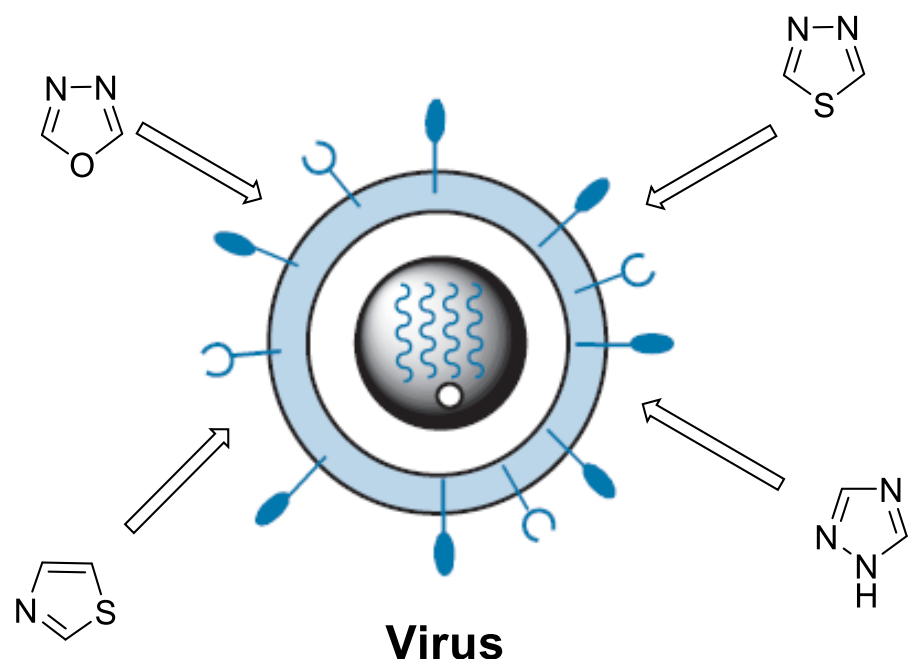

Keywords: Antiviral drugs, thiadiazoles, oxadiazoles, triazoles, thiazoles 


\section{Table of Contents}

1. Introduction

2. Thiadiazole-containing Compounds as Antiviral Agents

3. Oxadiazole-containing Compounds as Antiviral Agents

4. Triazole-containing Compounds as Antiviral Agents

5. Thiazole-containing Compounds as Antiviral Agents

References

\section{Introduction}

Viruses are non-cellular, infectious organisms that invade a host cell to survive and multiply. There are many different viruses capable of infecting animal, bacterial, or plant cells, with more than 400 known to infect humans. Those capable of being transmitted to humans from insects or animals can be particularly dangerous and belong to a class of diseases defined as zoonoses. ${ }^{1}$ The current most dangerous virus disease Coronavirus (COVID-19) is an infectious disease caused by a newly discovered coronavirus (SARS-CoV-2) that is transmitted from animal to human is an example of zoonoses. ${ }^{2}$ Consequently, both human and veterinary medicine play important roles in the control of such diseases. Historically, viral infections were devastating to mankind. It has been suggested that smallpox was the reason for the major epidemics which weakened the Roman Empire during the periods AD 165-180 and AD 251-266. ${ }^{3}$ Smallpox was a major cause for the high mortality in the indigenous tribes in both North and South America at the time of European colonization. ${ }^{4}$ Various flu epidemics and pandemics have proved devastating. The flu pandemic of 1918-1920 which was called Spanish flu left between 17 and 50 million deaths and 500 million infections worldwide, ${ }^{5}$ far larger than the number killed because of World War I. Finally, 32.7 million [24.8 million-42.2 million] people have died from AIDSrelated illnesses since the start of the epidemic in the early 1980 s. $^{6}$ Africa has its fair share of lethal viruses, including AIDs, Ebola, and the virus responsible for Lassa fever. ${ }^{7}$ Vaccination is the most effective method to protect against viral infection and has proved extremely successful against fetal childhood diseases such as measles, mumps, and rubella (MMR vaccine) ${ }^{8}$ as well as historically serious infections such as yellow fever ${ }^{9}$ and smallpox which was the first vaccine to be developed, in $1796 .{ }^{10}$ Antiviral remedies are useful in tackling viral infections where there is a lack of an effective vaccine or where the infection has already taken place. The antiviral agents may be non-nucleoside analogues: those which are a group of heterogeneous compounds and interact directly with the target, ${ }^{11}$ or nucleoside analogues: they must be activated intracellularly by phosphorylation to the active triphosphate form. ${ }^{12}$ Thiadiazoles and their isosteres, triazoles, oxadiazoles, and thiazoles have shown broad biological activities as mentioned in the next paragraph. Here we will focus on the antiviral activities of the agents containing the specified ring systems thiadiazoles, triazoles, oxadiazoles, and thiazoles.

Five-membered heterocyclic compounds have shown a wide range of biological activities, ${ }^{13}$ namely thiadiazoles, thiazoles, 1,3,4-oxadiazoles, triazoles, ${ }^{14-27}$ in addition to the benzimidazole ring. ${ }^{28}$ They have been used as scaffolds for the synthesis of a wide range of agents with versatile activities including antibacterial, ${ }^{29,30}$ antifungal, ${ }^{31,32}$ analgesic, anti-inflammatory, ${ }^{23}$ anticancer ${ }^{33,34}$ and antihypertensive activity. ${ }^{35}$

These five-membered heterocyclic rings have also proved to have very effective antiviral activity against a wide range of viruses, making them of great value in the antiviral research. ${ }^{36-41}$ 


\section{Thiadiazole-containing Compounds as Antiviral Agents}

Cui et al. $^{42,43}$ synthesized a series of pyrrolyl-1,3,4-thiadiazole derivatives of structure 1 which showed antiviral activity against the West Nile virus and Dengue virus.

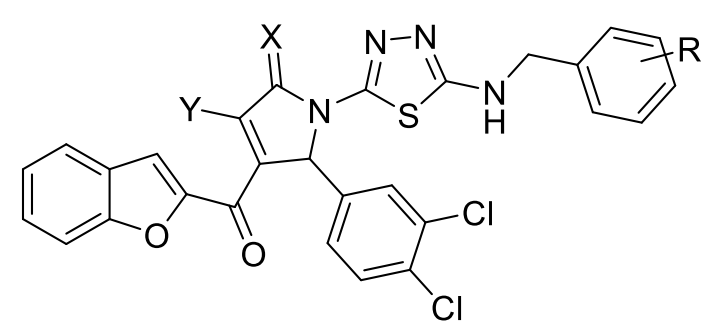

1

$\mathrm{X}=\mathrm{O}, \mathrm{S}, \mathrm{NH} ; \mathrm{Y}=\mathrm{OH}, \mathrm{SH} ; \mathrm{R}=\mathrm{H}, \mathrm{OH}, \mathrm{CN}$, halo, alkyl, alkoxy

Brai et al. $^{44}$ found that compound 2 of the newly synthesized series of 1,3,4-thiadiazole derivatives was the most promising as an anti-HIV-1 agent without in vitro signs of cytotoxicity.<smiles>O=C(O)c1ccccc1C(=O)Nc1nnc(-c2ccc(O)cc2)s1</smiles>

2

Tang et al. $^{45}$ have reported the synthesis of a series of benzothiazole derivatives bearing 1,3,4-thiadiazole moiety. The newly synthesized compounds exhibited good antivirus activity against tobacco mosaic virus, with compound 3 being the most effective.<smiles>COc1ccc2sc(NC(=O)CSc3nnc(-c4ccc([N+](=O)[O-])cc4)s3)nc2c1</smiles>

3

Zhong et al. $^{46}$ synthesized a series of novel myricetin derivatives linked to 1,3,4-thiadiazole species. Their antiviral activity against the tobacco mosaic virus was evaluated. Results showed that some of the compounds exhibited potential antiviral activity. Compounds $4 a-d$ had the best effect. 
<smiles>[R]CSc1nnc(CNc2c(-c3cc(OC)c(OC)c(OC)c3)oc3cc(OC)cc(OC)c3c2=O)s1</smiles>

$\mathrm{R}=$ 4-chlorophenyl, 2-chlorophenyl, 2,4-dichlorophenyl, 2-chlorothiazol-5-yl)

$\mathrm{Yu}$ et al. $^{47}$ found that 1,4-pentadien-3-one derived from curcumin proved to have remarkable activity against plant viruses. That is why a series of new derivatives containing a 1,3,4-thiadiazole moiety together with a 1,4-pentadien-3-one unit was synthesized. Most of the synthesized compounds showed good activity against the tobacco mosaic virus and cucumber mosaic virus with compounds $\mathbf{5 a - d}$ showing the best activity.

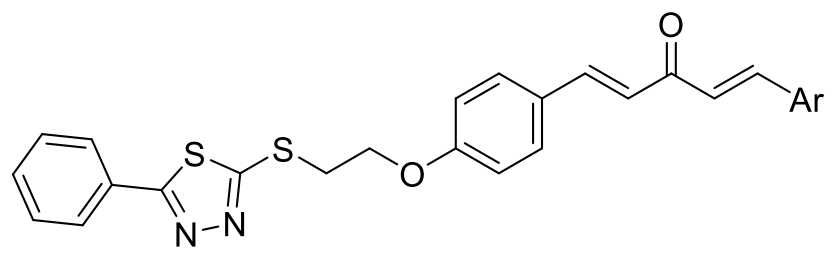

5a-d

$$
\mathrm{Ar}=4-\mathrm{F}-\mathrm{Ph}, 4-\mathrm{Br}-\mathrm{Ph}, 2-\mathrm{F}-\mathrm{Ph}, 3-\mathrm{NO}_{2}-\mathrm{Ph}
$$

Manvar et $a .^{48}$ synthesized a series of thiazolidinone-thiadiazole derivatives, of which compounds $6 \mathbf{a}, \mathbf{b}$ had a promising effect against the Dengue virus and can be used as lead compounds.<smiles></smiles>

\section{6a,b}

$$
\begin{array}{ll}
6 a R^{1}=C_{6} H_{4} F & R^{2}=C_{6} H_{4} F \\
6 b R^{1}=C_{6} H_{4} C l l^{2}=C_{6} H_{4} F
\end{array}
$$

Wu et al. ${ }^{49}$ prepared a novel series of 2-substituted methylthio-5-(4-amino-2-methylpyrimidin-5-yl-)-1,3,4thiadiazole derivatives. Bioassay screening showed that compounds $\mathbf{7 a - d}$ exhibited the best activity against the tobacco mosaic virus in vivo. 


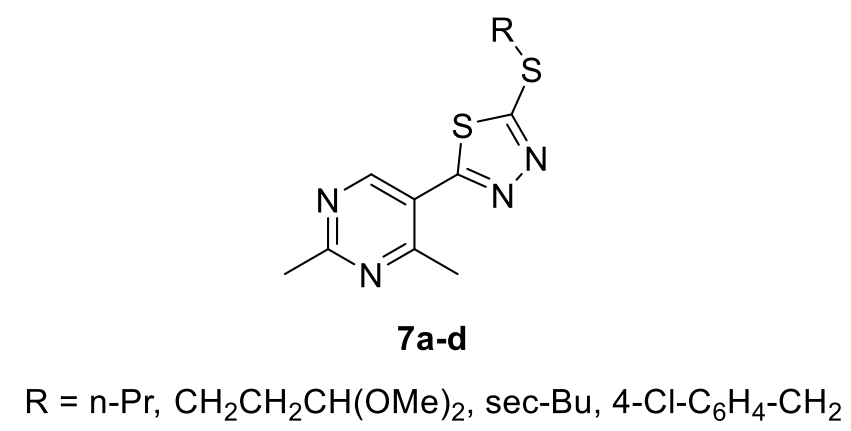

A novel series of thioether derivatives linked to 1,3,4-thiadiazole and emodin moieties were synthesized. The bioassay results showed that the thiadiazole derivative $\mathbf{8}$ showed excellent activity against the tobacco mosaic virus. ${ }^{50}$<smiles>COc1cc(OC)c2c(c1)C(=O)c1cc(CSc3nnc(C)s3)cc(OC)c1C2=O</smiles>

8

2-(2-Carbamothioylhydrazono)-N-(5-(4-methoxyphenyl)-1,3,4-thiadiazol-2-yl)acetamide (compound 9) was synthesized for exploring its antiviral activity; it showed high activity against the cowpea mosaic virus. ${ }^{51,52}$<smiles>COc1ccc(-c2nnc(NC(=O)C=NC(N)=S)s2)cc1</smiles>

9

Tatar et al. ${ }^{53}$ found that at subtoxic concentrations, compounds $10 \mathrm{a}-\mathrm{c}$ showed interesting antiviral activity against Herpes simplex-1 virus that can be considered as a lead for further work and research.

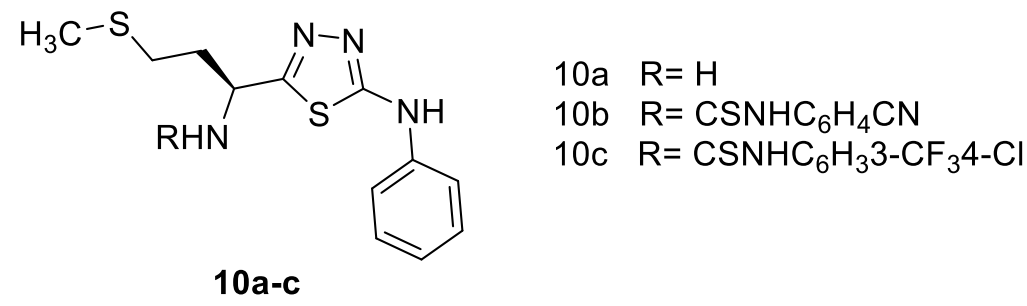

A series of thiazolidinone based heterocycles (compounds 11a-e) was synthesized and tested for their activity against varicella zoster virus and cytomegalovirus. Most of the produced compounds exhibited good activity ${ }^{54}$. 


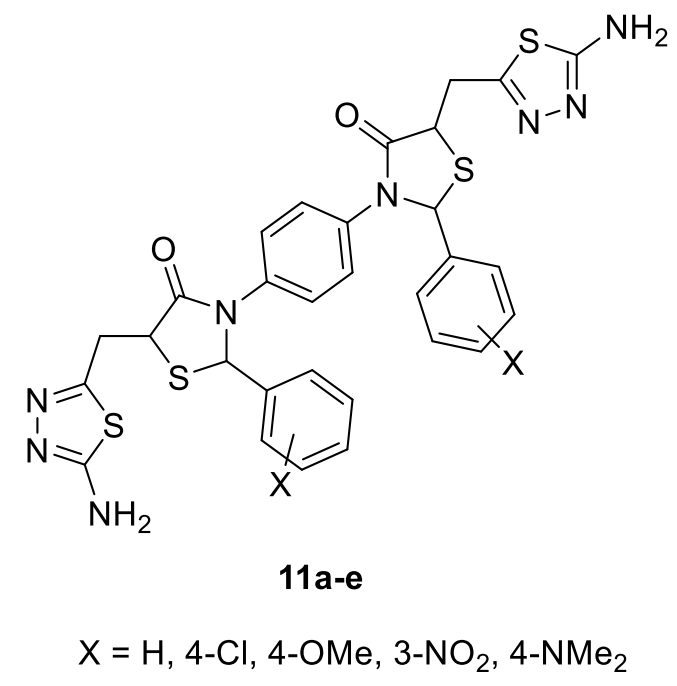

2-(4-Cyanobenzyl)-1-[3-(trifluoromethyl)phenyl]ethanone hydrazone derivatives (12) can be utilized in combination with commercial anti-plant virus agents to control diseases and viruses in agriculture, gardening and forestry. ${ }^{55}$

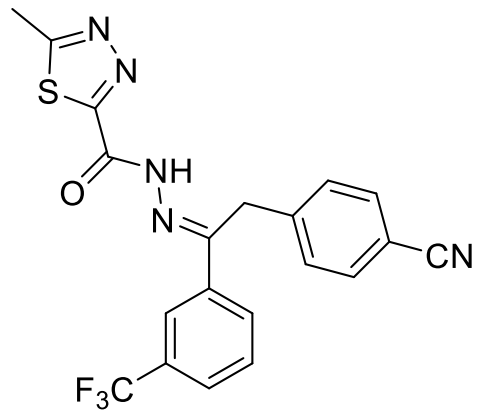

12

A new series of 4-oxo-4H-pyrido[1,2-a]pyrimidine derivatives linked to 1,3,4-thiadiazole ring was prepared. All the produced compounds exhibited moderate activity against HIV-1 with $13 \mathbf{a}, \mathbf{b}$ showing the best activity. $^{56}$

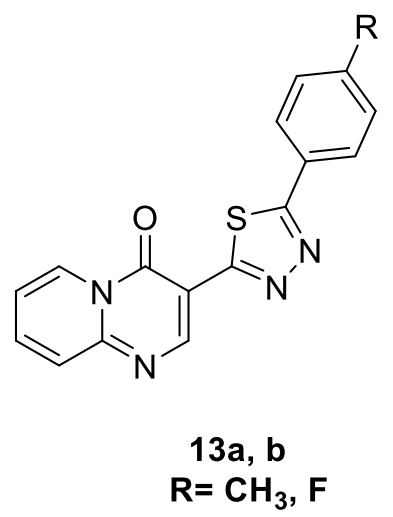

1,3,4,5-Tetrasubstituted $1 H$-pyrrol-2(5H)-one can be used as a scaffold for the synthesis of a new series of compounds against the West Nile virus. Of these, compound 14 showed the best activity. ${ }^{57}$ 


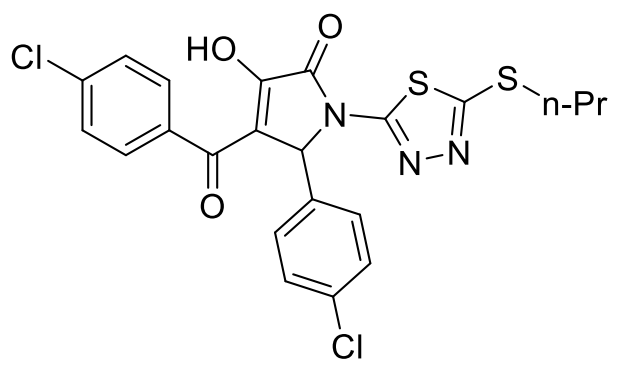

14

Xu et al. ${ }^{58}$ prepared a series of 2-(4-methyl-1,2,3-thiadiazolyl)-5-substituted-1,3,4-thiadiazole derivatives. The prepared compounds were tested for their antiviral activity. It was found that compound $\mathbf{1 5}$ exhibited an inhibition of $55 \%$ against the tobacco mosaic virus.

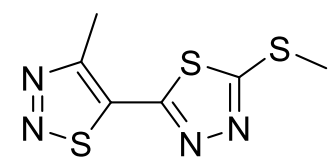

15

Wang et al. $^{59}$ synthesized a series of 1,2,3-thiadiazoles 16 a-c attached to a tetrazole moiety that proved to have a much better effect against the tobacco mosaic virus than that of ribavirin at $100 \mu \mathrm{g} / \mathrm{ml}$.

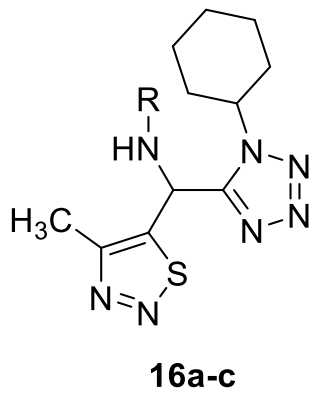

16a $R=$ Isopropyl

16b $R=$ Cyclopentyl

16c $\mathrm{R}=2$-Fluorophenyl

Zhuo Chen et al. ${ }^{60}$ described the synthesis of a new series of thiadiazole analogues hybridized with the sulfonamide group. These compounds proved to have moderate antiviral activity against the tobacco mosaic virus, especially compounds $17 \mathbf{a}, \mathbf{b}$.<smiles>[R]NS(=O)(=O)c1nnc(-c2ccc(Cl)cc2)s1</smiles><smiles>[Y17]=Cc1ccc(C)cc1</smiles>

$17 a, b$ 
Hamad et al. ${ }^{61,62}$ synthesized a series of 2-(naphthalen-2-yloxy)- $N$-[(5-(phenylamino)-1,3,4-thiadiazol-2$\mathrm{yl}$ )methyl] acetamide derivatives and examined them for in vitro activity against HIV-1 and anti-HIV-2. Of the synthesized compounds, compound $\mathbf{1 8}$ showed the best activity.<smiles>O=C(COc1ccc2ccccc2c1)NCc1nnc(Nc2ccccc2)s1</smiles>

A new series of 1,3-dioxo-1,3-dihydro-2-benzofuran-5-carboxamide derivatives linked to 1,3,4-thiadiazole was synthesized. The new compounds $19 a-c$ showed $100 \%$ inhibition of human cytomegalovirus ${ }^{63}$.

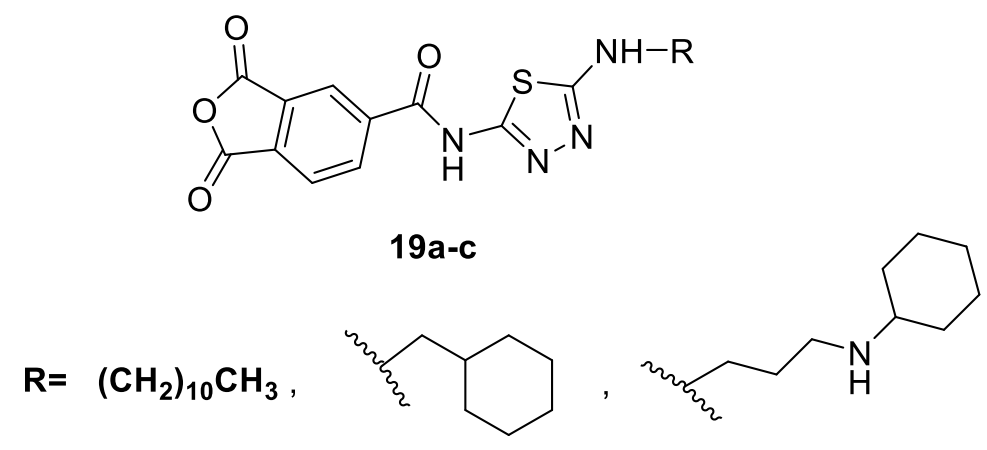

A series of 1,3,4-thiadiazole derivatives was prepared. The prepared compounds were found to have useful antiviral activity against cytomegalovirus (CMV). Most of the new compounds gave in vitro inhibition more than $90 \%$ of that of CMV polymerase. ${ }^{64}$

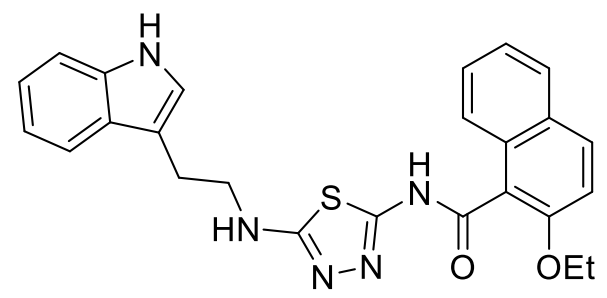

20

Parkanyi et al. $^{65}$ synthesized a group of thiadiazole quinazolone derivatives 21a-d for their antiviral investigation, these compounds showed moderate antiviral activity against HSV-1. 


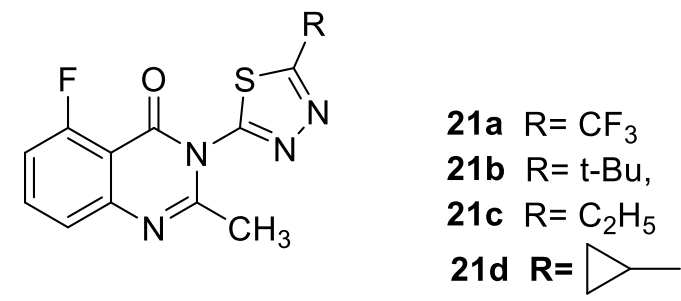

21a-d

Paget et al. ${ }^{66}$ found that compounds 22a-c exhibited useful antiviral activity against measles, vaccinia and HSV type I and II, compound 22a possessed in vivo activity, 22 $\mathbf{b}$ had both in vivo and in vitro activity and compound 22c proved to be extremely active in vitro.<smiles>C[As]/C(N)=N/c1nncs1</smiles>

$22 a$<smiles>N#CNc1nncs1</smiles>

22b<smiles>NC(N)=Nc1nncs1</smiles>

22c

Orzalesi et al. $^{67}$ found that a series of virucidal compounds containing 1,3,4-thiadiazole (compound 23) was active against herpes simplex-2 in vitro.<smiles>[R]Nc1nnc(-c2ccccc2S(=O)(=O)N[R])s1</smiles>

23

$\mathrm{R}=\mathrm{H}, \mathrm{Me}, \mathrm{Et}, \mathrm{Me}_{2} \mathrm{CH}, \mathrm{Bu}, \mathrm{H}_{2} \mathrm{C}: \mathrm{CHCH}_{2} ; \mathrm{R}^{1}=\mathrm{H}, \mathrm{Me}, \mathrm{Et}$

Jones et al. $^{68}$ was able to synthesize a group of thiadiazolyl pyridine derivatives $\mathbf{2 4 a - b}$ for exploring their antiviral activity against neurovaccinia virus in mice. The results showed that the thiadiazole derivatives have excellent antiviral activity.<smiles>[R]Nc1nnc(-c2cccnc2)s1</smiles>

$24 a, b$ 24a $\mathrm{R}=\mathrm{H}$

24b $\mathrm{R}=\mathrm{COCH}_{3}$

\section{Oxadiazole-containing Compounds as Antiviral Agents}

The 1,3,4-oxadiazole ring is considered a privileged structure in antiviral chemotherapy, ${ }^{69}$ it is a molecular framework that can provide beneficial ligands for various receptors and enzymes by some modifications in the structure. $^{70}$ 
This heterocycle has proved to have very potent activity against a wide range of viruses such as human immunodeficiency virus (HIV), ${ }^{39,71}$ influenza virus, hepatitis A virus (HAV), ${ }^{36}$ hepatitis $B$ virus (HBV), ${ }^{36}$ hepatitis C virus (HCV), ${ }^{36}$ herpes simplex virus (HSV), cytomegalovirus (CMV), varicella zoster virus (VZV). ${ }^{72,73}$

Hamdani et al. ${ }^{74}$ linked together two pharmaceutically interesting motifs, 1,3,4-oxadiazole, and benzene sulfonamide in two series to develop novel hybrids. Bioactivity assays showed that $\mathbf{2 5 a} \mathbf{a} \mathbf{b}$ are the most potent inhibitors among the synthesized analogs against dengue virus protease.

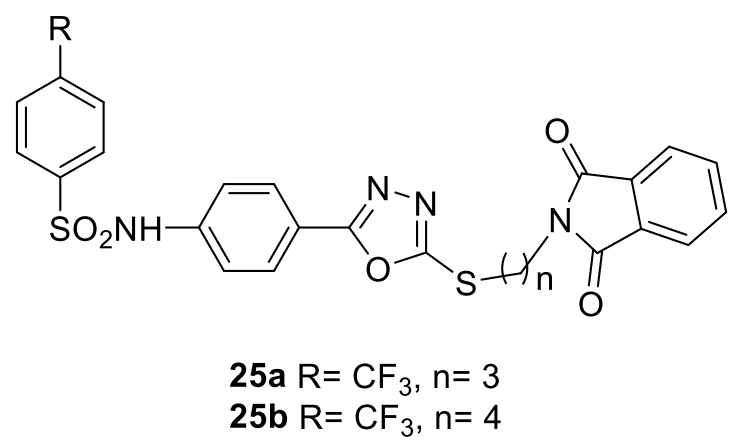

The human rhinovirus (HRV) is the main cause of common cold that leads to respiratory complications, the high rate of mutations limits the development of anti-HRV drugs, which urges the need for discovery of new lead compounds.

Kim et al. ${ }^{75}$ synthesized compound $\mathbf{2 6}$ which showed antiviral activity and was further used for the synthesis of a series of compounds which proved to have high efficacy against HRV-A and B. Compound 27 exhibited a high efficacy against HRV-B14, HRV-A21, and HRV-A71H.<smiles>CNC(=O)c1cc(Oc2ccc3c(C)c(C(=O)C(C)C)sc3c2)ccn1</smiles>

26<smiles>CNC(=O)c1cc(Oc2ccc(-c3noc(C(C)C)n3)c(C)c2)ccn1</smiles>

27

Gan et al. ${ }^{76}$ synthesized a series of novel 1,3,4-oxadiazole/thiadiazole-chalcone conjugates, compounds 28a, $\mathbf{b}$ were found to possess remarkable activity against tobacco mosaic virus both in vitro and in vivo. 


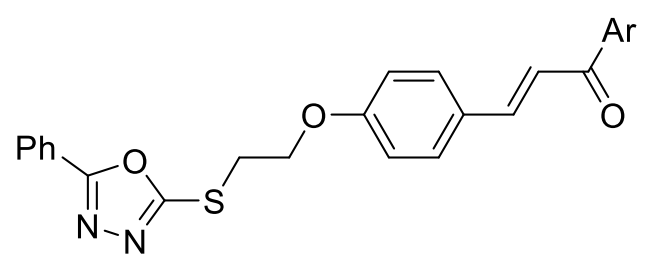

$28 a, b$

28a $\mathrm{Ar}=2,4-\mathrm{diCl}-\mathrm{Ph}$

28b Ar= thiophen-2-yl

2-(1,3,4-Oxadiazol-2-yl)-3-aminothieno[2,3-b]pyridine derivatives (compounds 29) have been synthesized, and were found useful against hepatitis $\mathrm{C}$, also giving an idea for further development of anti-HIV agents. ${ }^{77}$

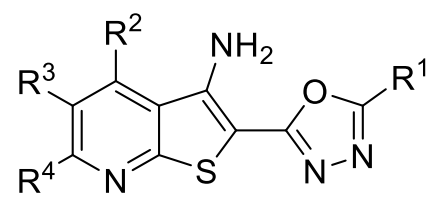

29

Chudinov et al. ${ }^{78}$ prepared new ribofuranosyl oxadiazolyl triazole derivatives (compound 30a-d) which were tested against herpes simplex, influenza $A$ and hepatitis $C$ viruses showing high efficacy.<smiles>[R]c1nc(-c2ncn([C@@H]3O[C@H](CO)[C@@H](O)[C@H]3O)n2)no1</smiles>

$30 \mathrm{a} \mathrm{R}=\mathrm{H}$

30b R= $\mathrm{CH}_{3}$

30c $\mathrm{R}=$ iso- $\mathrm{Pr}$

30d $\mathrm{R}=\mathrm{Ph}$

Wang et al. $^{79}$ prepared diamide 1,3,4-oxadiazole derivatives, compound 31 showed the best effect against tobacco mosaic virus in vivo that it can act as a lead compound.<smiles>Cc1nnc(CNC(=O)c2ccccc2NC(=O)[GeH2])o1</smiles>

Gan et al. ${ }^{80}$ designed a series of 1,4-pentadien-3-one derivatives containing 1,3,4-oxadiazole, of which compound 32 showed excellent activity against the tobacco mosaic virus. 


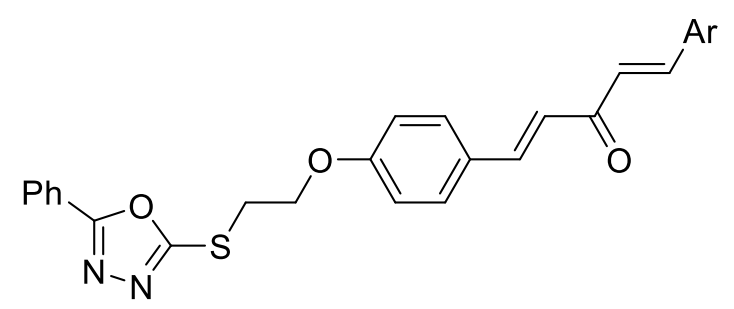

32

Bioassay screening showed that the 1,3,4-oxadiazole acetamide derivatives (compound 33) showed remarkable activity against tobacco mosaic virus that it can act as an alternative candidate for other antiviral drugs. $^{81}$<smiles>[R]c1ccc(NC(=O)CSc2nnc([R])o2)cc1</smiles>

$$
\begin{aligned}
& \mathbf{R}^{1}=2-\mathrm{ClC}_{6} \mathrm{H}_{4}, 3-\mathrm{ClC}_{6} \mathrm{H}_{4}, 4-\mathrm{ClC}_{6} \mathrm{H}_{4}, 4-\mathrm{FC}_{6} \mathrm{H}_{4}, 4-\mathrm{ClC}_{6} \mathrm{H}_{4} \mathrm{CH}_{2} \\
& \mathbf{R}^{2}=\mathrm{CH}_{3}, \mathrm{OCH}_{3}, \mathrm{NO}_{2}, \mathrm{~F}, \mathrm{Cl}, \mathrm{Br}
\end{aligned}
$$

A new series of 2-(thieno[2,3-b]pyridin-2-yl)-1,3,4-oxadiazole scaffold was produced for further investigation against HCV, compound $\mathbf{3 4}$ was found to be the most potent of the designed compounds. ${ }^{82}$

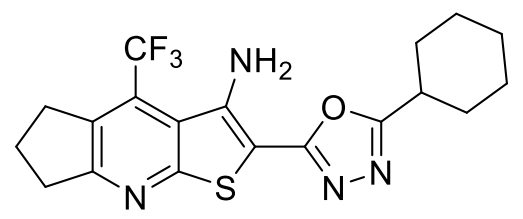

34

Benmansour et al. $^{83}$ reported the synthesis and antiviral activity of compound $\mathbf{3 5}$ and $\mathbf{3 6}$ derived from a rapid and easy chemical route. Compounds prepared by this method possessed in vitro activity against the polymerase enzyme of the Dengue virus. The following series of oxadiazole derivatives showed a submicromolar activity against the four dengue virus serotypes.

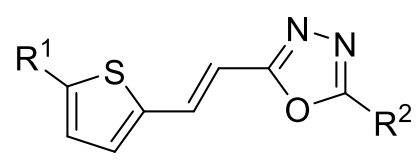

35

$$
\mathrm{R}^{1}=\mathrm{Br}, \mathrm{C}_{6} \mathrm{H}_{5} ; \mathrm{R}^{2}=3-\mathrm{ClC}_{6} \mathrm{H}_{4}, 3-\mathrm{MeOC}_{6} \mathrm{H}_{4}, 4-\left(\mathrm{CH}_{3}\right)_{2} \mathrm{NC}_{6} \mathrm{H}_{4}
$$

36

$$
\mathrm{R}^{3}=3-\mathrm{ClC}_{6} \mathrm{H}_{4}, 4-\mathrm{ClC}_{6} \mathrm{H}_{4}, 4-\mathrm{OCF}_{3} \mathrm{C}_{6} \mathrm{H}_{4}, 4-\mathrm{CF}_{3} \mathrm{C}_{6} \mathrm{H}_{4}
$$


Raltegravir (compound 37) ${ }^{84}$ marketed as Isentress is an antiretroviral drug produced by Merck and Co., was approved by U. S. Food and Drug Administration (FDA) in 2007 and was approved for infant use in 2011, used for the treatment of HIV infections. This drug contains an oxadiazole ring in its basic skeleton. ${ }^{59,60}$<smiles>Cc1nnc(C(=O)NC(C)(C)c2nc(C(=O)Nc3ccc(F)cc3)c(O)c(=O)n2C)o1</smiles>

37

Iqbal et al. $^{85}$ studied the antiviral effect of introducing 1,3,4-oxadiazole moiety to benzenesulfonamide, one of the synthesized compounds $\mathbf{3 8}$ was found to be the most active against HIV. ${ }^{76,77}$<smiles>NS(=O)(=O)c1cc(-c2nnc(S)o2)ccc1Cl</smiles>

38

Wu Wenneng et al. $^{86}$ synthesized a new series of 2-substituted methylthio-5-(4-amino-2methylpyrimidin-5-yl-)-1,3,4-oxadiazole derivatives. Of these, compound 39 exhibited excellent activity against tobacco mosaic virus.<smiles>COC(=O)CSc1nnc(-c2cnc(C)nc2N)o1</smiles>

39

1,3,4-Oxadiazole derivatives (compound 40) were prepared and found to have an inhibitory effect against tobacco mosaic virus. ${ }^{87}$<smiles>[R][X]c1nnc(Nc2ccc([R])cc2)o1</smiles>

40

$\mathrm{X}=\mathrm{S}$ or $\mathrm{SO}_{2}$

$\mathrm{R}^{1}=\mathrm{Me}, \mathrm{Et}$, or (un)substituted benzyl

$\mathrm{R}^{2}=$ halo, alkyl, or alkoxy

5-Benzyl-N-phenethyl-1,3,4-oxadiazole-2-carboxamide derivatives (compound 41) were synthesized and tested for their activity against the Flaviviridae family of viruses, such as HCV. ${ }^{88}$ 


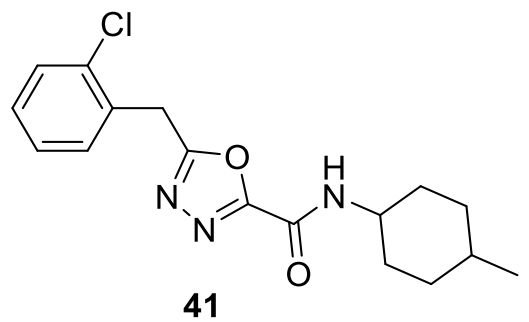

A series of raltegravir derivatives were synthesized and examined for their activity against HIV. The results showed that most of the compounds exhibited good to excellent activity with compound $\mathbf{4 2}$ showing the most potent activity. ${ }^{89}$

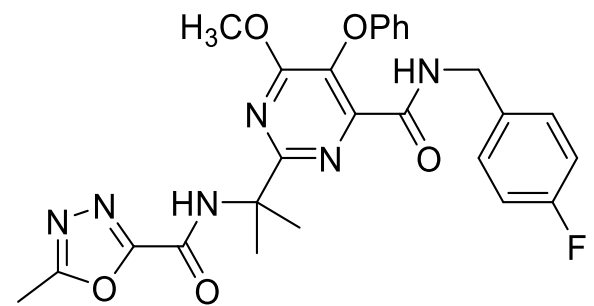

42

The 1,2,4-oxadiazole analog is a potent nucleoside inhibitor of Hepatitis C virus (HCV) NS5B polymerase. Compound $\mathbf{4 3}$ showed high antiviral potency against HCV replication in replicon cells and efficient conversion to the corresponding NTP in vivo, NTP level was very high in rat liver following i.v. and oral administration. ${ }^{90}$

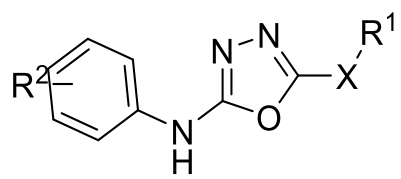

43

$\mathrm{X}=\mathrm{S}$ or $\mathrm{SO}_{2}$

$\mathrm{R}^{1}=\mathrm{Me}, \mathrm{Et}$, or (un)substituted benzyl

$\mathrm{R}^{2}=$ halo, alkyl, or alkoxy

Syed et al. ${ }^{91}$ synthesized a new series of 5-benzylthio-1,3,4-oxadiazoles 44a-c for their expected antiviral activity. Their activity was tested against HIV-I and HIV-II and showed high inhibitory activity against both viruses.<smiles>[X]c1ccc(CSc2nnc(C([R])NS(=O)(=O)c3ccc([R])cc3)o2)cc1</smiles>

44a-c $\begin{array}{llcc} & \mathrm{R} & \mathrm{R}^{\prime} & \mathrm{X} \\ \text { 44a } & \mathrm{CH}_{3} & \mathrm{Cl} & \mathrm{Br} \\ \text { 44b } & \left(\mathrm{CH}_{2}\right)_{2} \mathrm{SCH}_{3} & \mathrm{CH}_{3} & \mathrm{Br} \\ \text { 44c } & \mathrm{CH}_{2} \mathrm{Ph} & \mathrm{CH}_{3} & \mathrm{H}\end{array}$ 
A new series of 2,5-disubstituted 1,3,4-oxadiazole 45a,b and $\mathbf{4 6}$ were synthesized and evaluated against HIV and HCV, the results showed that the activity against HIV was in the order 45a followed by $45 \mathrm{~b}$ and then 46, while as anti-HCV, compound 46 has the highest activity followed by $\mathbf{4 5 a}$ then $\mathbf{4 5 b} .^{92}$<smiles>[R]CSc1nnc(COc2cccc3ccccc23)o1</smiles>

$45 a, b$<smiles>N=C(N)CCn1nc(COc2cccc3ccccc23)oc1=S</smiles>

46

45a $\mathrm{R}=\mathrm{CONHNCH}_{2}-\mathrm{D}$-xylotetritolyl

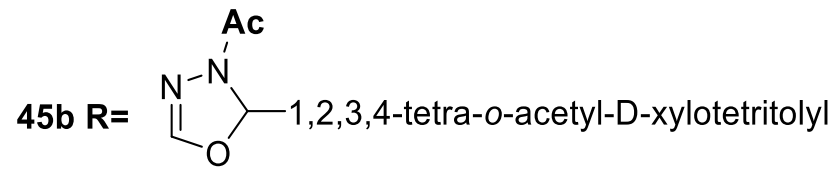

QSAR model was done for studying the inhibition of HIV-1 integrase on recently discovered 1,3,4oxadiazole substituted naphthyridine derivatives. Amongst them, compound $\mathbf{4 7}$ showed the best activity. ${ }^{93}$<smiles>CC(=O)Nc1cccc(-c2nc(-c3nnc(Cc4ccc(F)cc4)o3)c(O)c3ncccc23)c1</smiles>

Johns et al. ${ }^{94}$ found that the 1,3,4-oxadiazole derivative (compound 48) was a very potent HIV-1 integrase inhibitor. ${ }^{37}$ Modification of substitution at C5 of the naphthyridine ring yielded other oxadiazole derivatives 49a-f with comparable HIV-1 integrase inhibitory activity. 
<smiles>O=S1(=O)CCCCN1c1nc(-c2nnc(Cc3ccc(F)cc3)o2)c(O)c2ncccc12</smiles>

48<smiles>[R]c1nc(-c2nnc(Cc3ccc(F)cc3)o2)c(O)c2ncccc12</smiles>

49a-f<smiles>CN1CCCS1(=O)=O</smiles>

$\mathbf{R}=$<smiles>CN1CCN(C)S1(=O)=O</smiles>

49b<smiles>[13CH3]N1CCNC(=O)C1</smiles>

49d<smiles>CN1CCCNC1=O</smiles>

$49 e$<smiles>CN1CCOC1=O</smiles>

49c<smiles>CN1CCCN(C)S1(=O)=O</smiles>

$49 f$

Di Francesco et al. ${ }^{95}$ synthesized 1,3,4-oxadiazole derivative (compound 50) which showed excellent cellular anti-HCV activity.

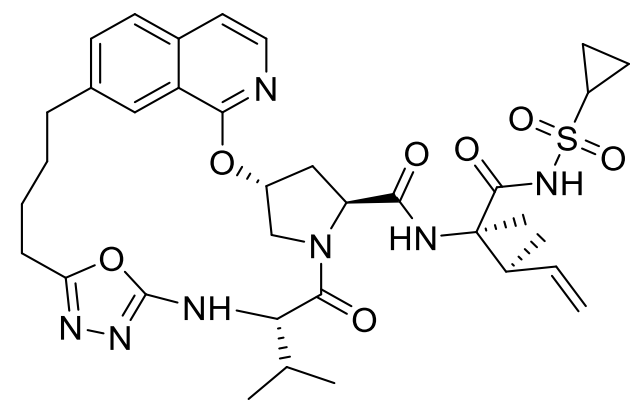

Recent literature showed that 1,3,4-oxadiazole scaffold is present in many HIV-1 inhibitors, acting by different mechanisms, through inhibition of viral reverse transcriptase, protease or integrase. ${ }^{96}$

Barreiro et al. ${ }^{97}$ prepared a new series of oxadiazole compounds 51a-c and was tested for the activity as HIV-1 reverse transcriptase inhibitors, these compounds showed potent activity as inhibitors of the viral enzyme.

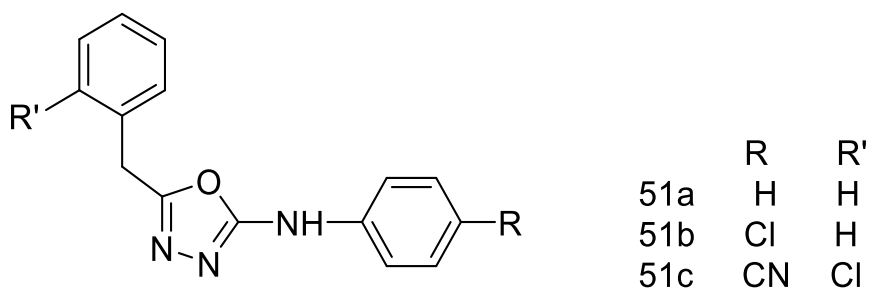

51a-c 
El-Assawy et al. $^{98}$ synthesized a series of 1,3,4-oxadiazole derivatives to be tested against HBV. Of the synthesized series, compound $\mathbf{5 2}$ showed the best activity with the least cytotoxicity.<smiles>CSCc1nnc(Cn2c(C)cc(C)c(C#N)c2=O)o1</smiles>

52

Compounds 53a-f were synthesized containing 1,3,4-oxadiazole ring. These compounds showed excellent anti-HIV activity against wild types and resistant strains. ${ }^{72}$
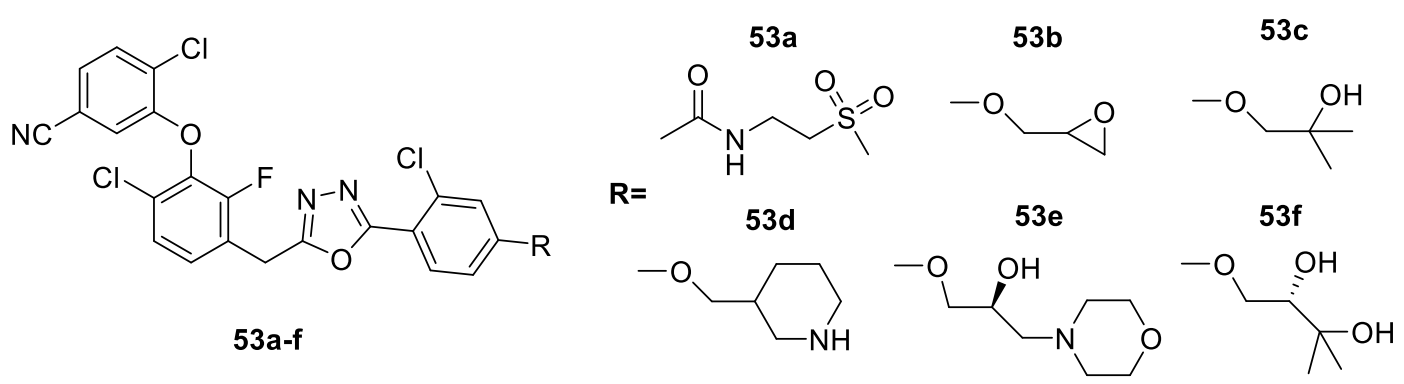

A series of $\mathrm{N}$-arylaminomethyl-1,3,4-oxadiazole derivatives was prepared, the synthesized compounds were tested against herpes simplex virus type-1 (HSV-1) and Hepatitis-A virus (HAV). The sugar hydrazones 54 a, $\mathbf{b}$ showed the best antiviral activity of all the synthesized compounds. ${ }^{99}$<smiles>[R]c1ccc(NCc2nnc(N/N=C/[C@@H](O)[C@@H](O)[C@H](O)CO)o2)cc1</smiles>

Cullen et al. ${ }^{100}$ synthesized new 1,3,4-oxadiazole analogues 55a, b that showed improved anti-HIV activity together with enhanced metabolic stability in rats.

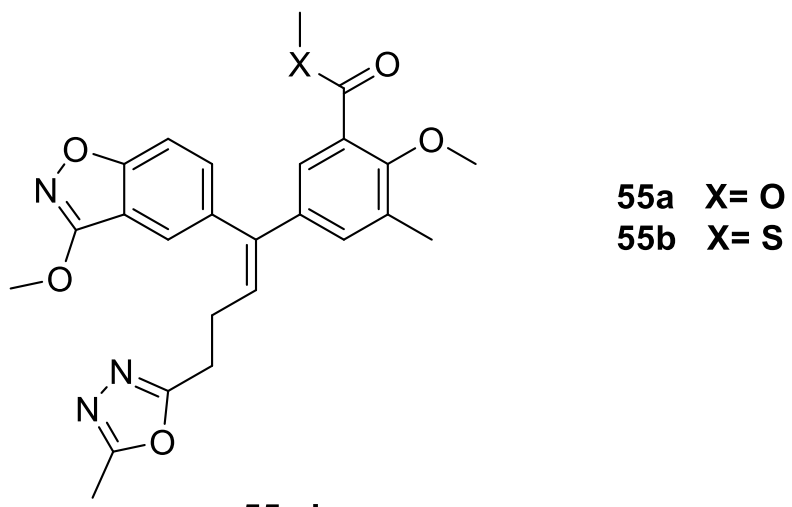

$55 a, b$ 
The dihydrochloride salt of the trifluoromethyl-substituted oxadiazole compound $\mathbf{5 6}$ showed good antipicornavirus activity. ${ }^{101}$

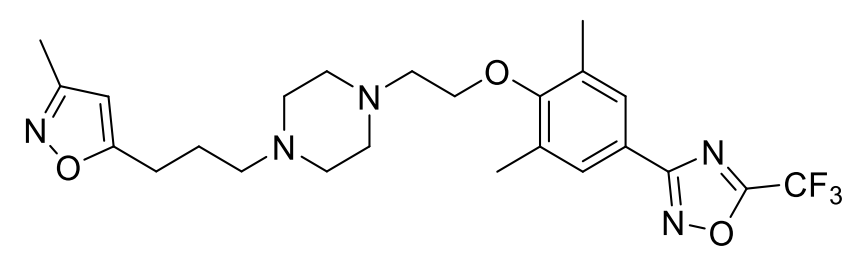

56

Tan et al. ${ }^{102}$ were able to synthesize the oxadiazole derivative $\mathbf{5 7}$, this compound showed excellent activity against hepatitis $B$ virus comparable to that of lamivudine. ${ }^{103}$<smiles>Nc1ccn(C2CSC(CO)O2)c(=O)n1</smiles>

Lamivudine

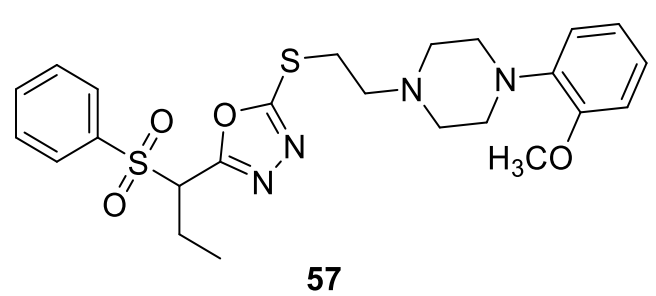

57

The anti-HIV activity of 5-adamantyl-1,3,4-oxadiazole-2-thione (compound 58) was studied. It showed excellent activity at different concentrations. ${ }^{40}$<smiles>S=c1[nH]nc(C23CC4CC(CC(C4)C2)C3)o1</smiles>

58

A new oxadiazole derivative (compound 59) was synthesized by a novel method through diastereoselective installing of a carboxylic acid and transforming it into the heterocycle. This compound showed excellent HIV-1 protease inhibition. ${ }^{104}$<smiles>O=C(NCC(F)(F)F)[C@H](Cc1nnco1)C[C@@H](O)CN1CCNC[C@H]1C(=O)NC[C@@H]1COc2ccccc2O1</smiles> 


\section{Triazole-containing Compounds as Antiviral Agents}

Many triazole-based compounds are available in the market as drugs. The triazole derivative 60 was used as a precursor for the synthesis of new antiviral agents that showed remarkable activity against HBV. ${ }^{105}$

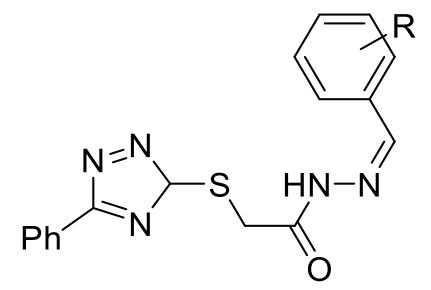

60

$\mathrm{R}=3,4-(\mathrm{OMe})_{2}, 3,5-\mathrm{Cl}_{2}, 4-\mathrm{Me}_{2} \mathrm{~N}, 2,4-(\mathrm{OH})_{2}, 2-\mathrm{OH}-1-$ naphthyl

Triazolopiperidines $\mathbf{6 1 a} \mathbf{a} \mathbf{b}$ were synthesized and tested for their anti-HIV activity. They were found to be very potent agents. ${ }^{106}$

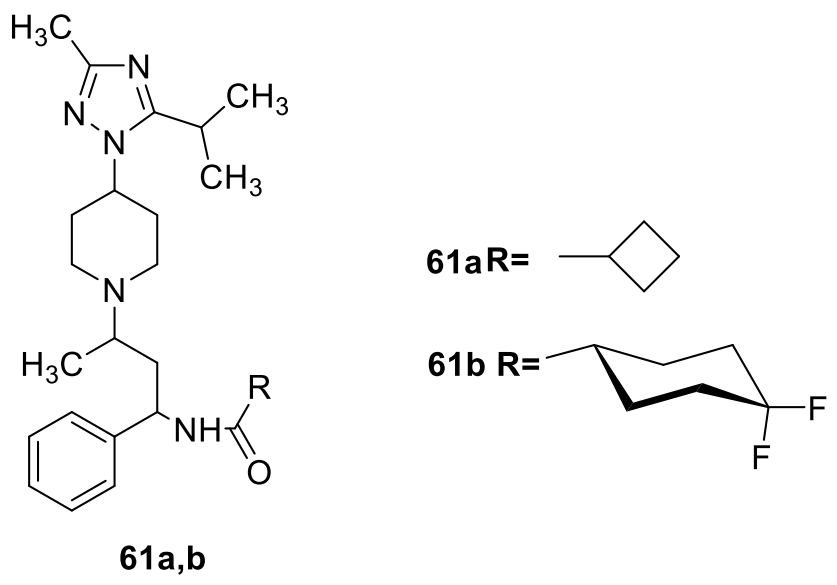

A series of 1,2,4-triazole derivatives was synthesized and tested for activity against HCV. Compound 62 was found to have the best activity. ${ }^{107}$

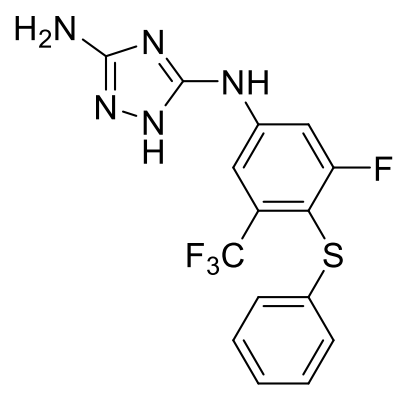

62

A new series of triazole derivatives was synthesized and examined for their activity against HCV. ${ }^{108}$ 
<smiles>Nc1nc(Nc2cc(Cl)c(Br)c(Cl)c2)n[nH]1</smiles>

Fostemsavir (compound 64) BMS-663068; experimental HIV-entry inhibitor prodrug, it offers a promise for individuals with HIV-resistant infections. ${ }^{109}$

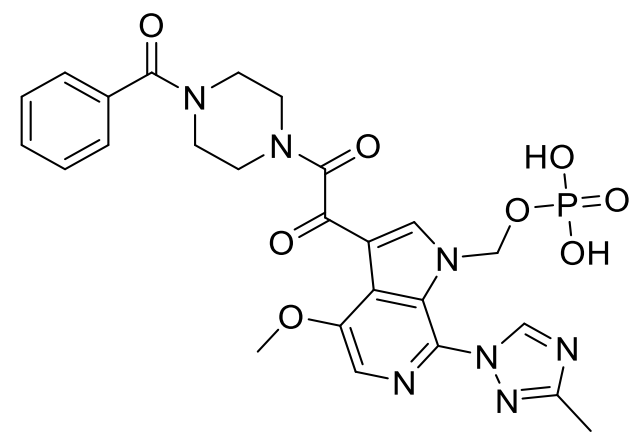

64

A new series of triazolyl-1,3,5-triazines was synthesized. Compound 65 showed high anti-HSV activity. ${ }^{110}$<smiles>Nc1nc(CSc2nnc(-c3ccccc3)n2/N=C/c2ccccc2)nc(Nc2ccccc2)n1</smiles>

65

A series of new compounds was synthesized through the reaction of $N^{3}$-substituted amidrazones together with cyclohexane dicarboxylic anhydride. Of the newly synthesized compounds, compound 66 showed the best anti-HIV-1 activity. ${ }^{111}$ 


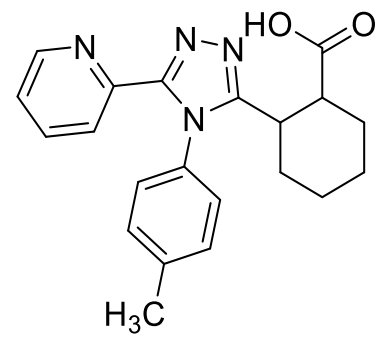

66

Benci et al. ${ }^{112}$ synthesized a series of triazole cyclopropane analogues $67 a-d$, these compounds showed moderate antiviral activity against vaccinia and Punta toro viruses that cause an acute febrile illness. ${ }^{113}$
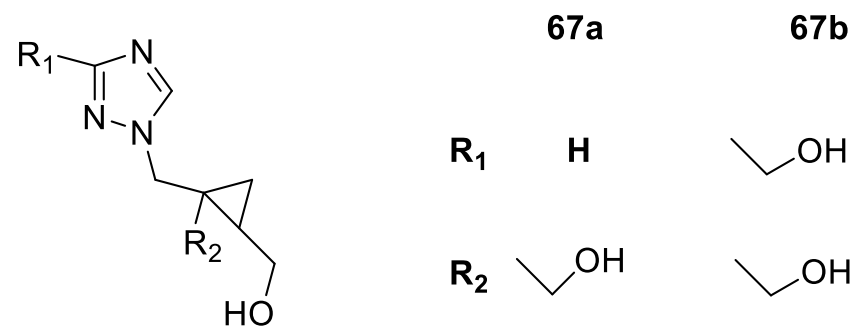

$67 b$

$67 \mathrm{c}$

$67 d$

$67 a-d$

The synthesis of diazo-triazoles was reported; compounds $68 \mathbf{a}, \mathbf{b}$ showed good activity against HSV-1. ${ }^{114}$

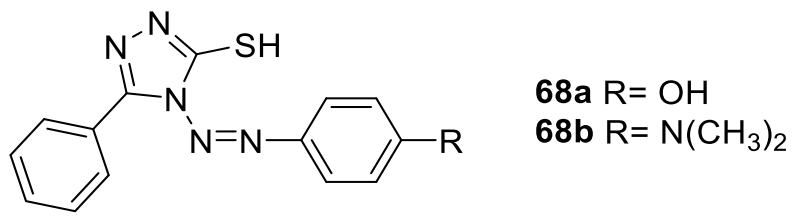

$68 a, b$

1- $\beta$-D-ribofuranosyl-3-ethynyl-1,2,4-triazole (ETAR) (compound 69) significantly reduced the replication of dengue virus. Moreover, it also reduced the replication of five flaviviruses, Langat virus (a flavivirus that causes encephalitis) and Modoc virus that cause fever or chills, cough, shortness of breath or difficulty breathing. That is why it represents a promising lead compound for treatment of flavivirus infections. It also proved to be active against Hantaan virus (HTNV) and Andes virus that cause fever, headache, nausea, and muscle ache. ${ }^{115,116}$

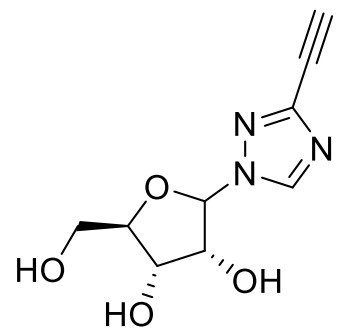


Maraviroc (compound 70) marketed as Selzentry or Calsentri outside U.S.A., is an antiretroviral agent used for treatment of HIV-1 infections, first developed by Pfizer, and was fully approved in $2007{ }^{117}$

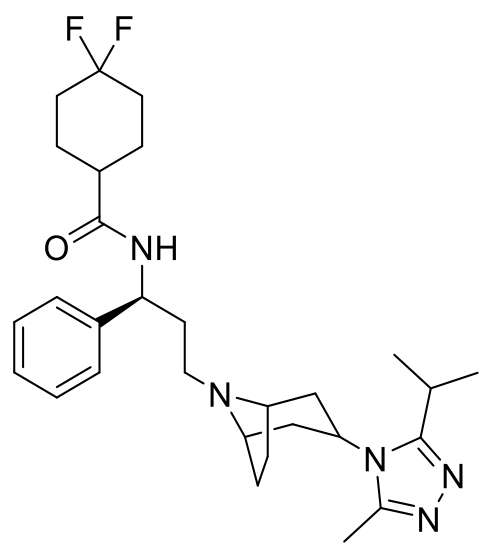

70

A new pharmacophore named 8-hydroxy-1,6-naphthyridine together with 1,2,4-triazole was identified; the two moieties were selected for the synthesis of the key structural components 71a, $\mathbf{b}$ which showed high anti-HIV-1 activity. ${ }^{37}$

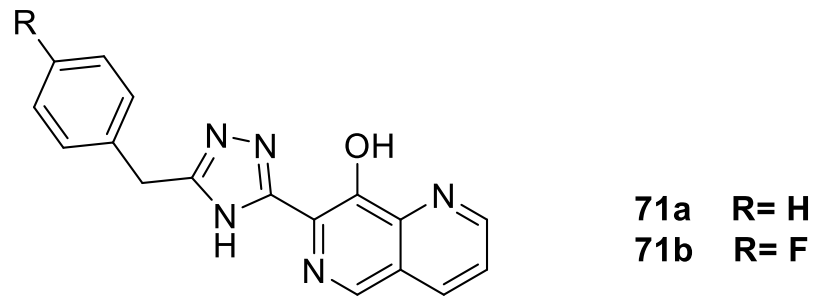

71a-b

Zhou et al. ${ }^{118}$ synthesized acyclic nucleoside triazole (compound 72 ) which was able to successfully inhibit HIV replication. ${ }^{119}$

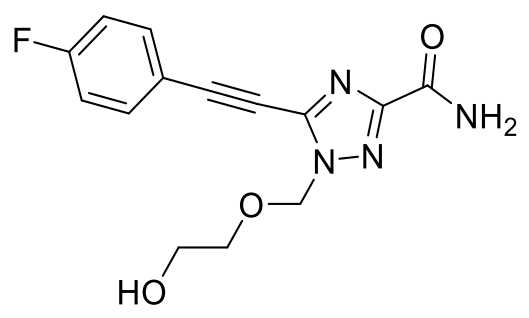

72

Johns et al. ${ }^{120}$ synthesized triazole naphthyridine compound $\mathbf{7 3}$ which displayed excellent activity against HIV-1 integrase. 


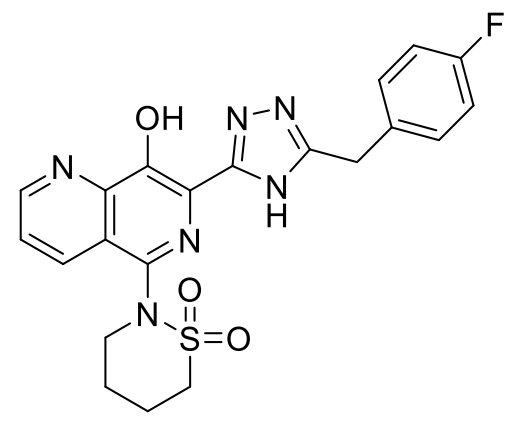

Küçükgüzel et al. ${ }^{121}$ synthesized some new triazole derivatives, 1-\{4-[(4-allyl-5-thioxo-4,5-dihydro- $1 H$ 1,2,4-triazol-3-yl)methoxy]phenyl\}-3-phenyl-thiourea (74) proved to have good activity against varicella-zoster virus and Coxsackie virus.<smiles>C=CCn1c(COc2ccc(NC(=S)Nc3ccccc3)cc2)n[nH]c1=S</smiles>

74

Zhu et al. ${ }^{122}$ synthesized a series of new acyclic triazole nucleosides $75 a-h$ which were tested for their antiHCV activity. All the new compounds, except 75b, exhibited good antiviral activity.

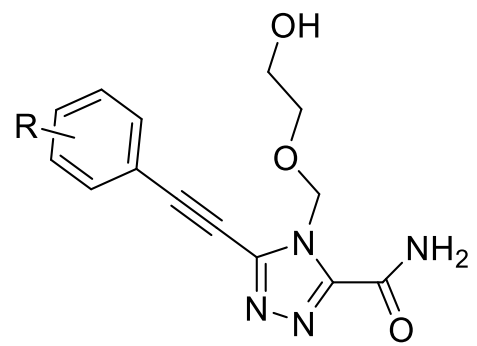

75a-h

$\mathrm{R}=\mathrm{H}, 4-\mathrm{OCH}_{3}, 4-\mathrm{CH}_{3}, 4-\mathrm{C}_{5} \mathrm{H}_{11}, 4-\mathrm{CF}_{3}, 4-\mathrm{F}, 3-\mathrm{F}, 2-\mathrm{F}$

A novel series of 3,4,5-trisubstituted 1,2,4-triazole derivatives was synthesized and tested for HIV-1 RT inhibitory activity. The bioassay results showed that compounds $\mathbf{7 6} \mathbf{a}, \mathbf{b}$, and $\mathbf{7 7}$ were the most active NNRTIs. ${ }^{123}$ 


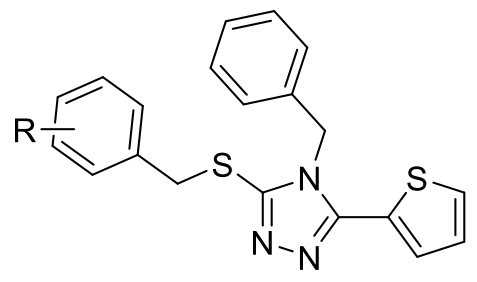

$76 a, b$<smiles>Clc1ccccc1CSc1nnc(-c2ccsc2)n1Cc1ccccc1</smiles>

$\mathrm{R}=\mathrm{H}, 2-\mathrm{Cl}$

New approaches for viral therapy have been developed to overcome the rapid emergence of resistant strains of retrovirus. Vivet Boudou et al. tested the activity of 1-(2'-deoxy--D-ribofuranosyl)-1,2,4-triazole-3carboxamide (2'-deoxy-ribavirin) compound 78 on HIV-1. ${ }^{124,125}$

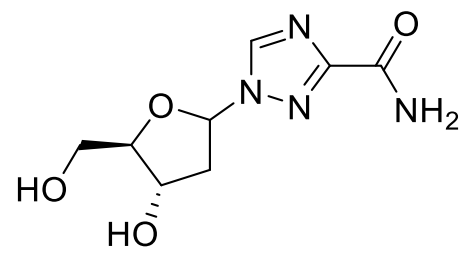

78

Kumarapperuma et al. ${ }^{126}$ synthesized a group of new ribavirin analogues to be tested against RNA viruses. Of the synthesized compounds, $\mathbf{7 9}$ showed the best activity.

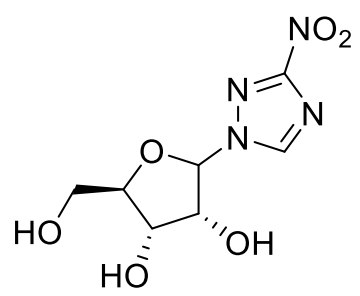

79

The synthesis of novel sulfanyltriazole derivative $\mathbf{8 0}$ was reported for further screening as an anti-HIV agent. This compound unexpectedly showed very potent anti-HIV activity that can be considered as a lead for further optimization. ${ }^{127,128}$

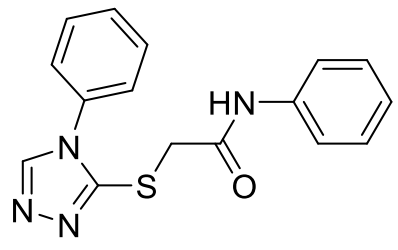

80

De La Rosa and co-workers were able to synthesize triazole derivatives $\mathbf{8 1 a , b}$ that were found to be highly active against nevirapine HIV-resistant strains with compound 81 a as the most active compound. ${ }^{129}$ 


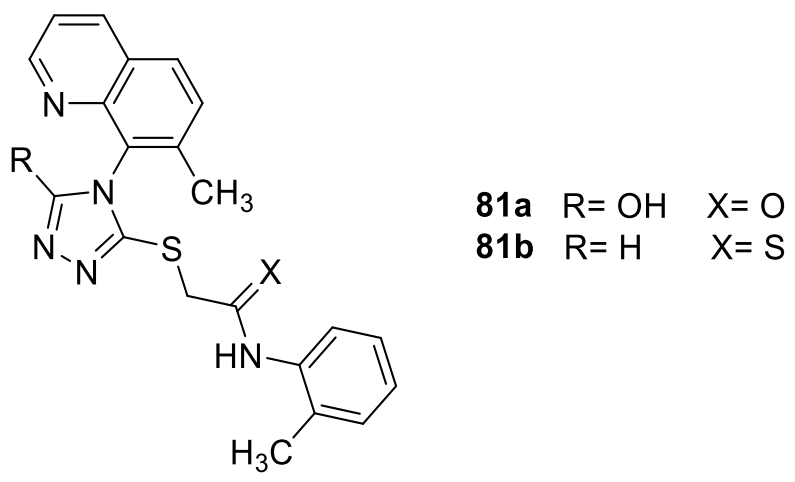

$81 a, b$

Ribavirin (82a) marketed as Hepavirin, Panvirin or Rebetol is a well-known antiviral drug used mainly for the treatment of HCV infections. This drug contains 1,2,4-triazole ring in its basic skeleton. It was first made in 1972 by researchers from international chemical and nuclear corporations and proved to have excellent activity against a wide range of RNA and DNA viruses. It was approved in the U.S.A. in 1998 and is now produced by Schering-Plough. ${ }^{130}$

Taribavirin (82b) also known as Viramidine is a Ribavirin prodrug in phase III human trials showed to be active against the influenza virus. It is better liver targeting than ribavirin, designed to concentrate in the liver, and expected to replace it in the treatment of hepatitis infections. Although it showed $38 \%$ viral inhibition compared to $52 \%$ for approved ribavirin, but it showed more safety from hemolytic anemia than ribavirin, that's why Valeant indicated the drug was on track by the end of $2007 .{ }^{131}$<smiles>[X]C(N)c1ncn([C@@H]2O[C@H](CO)[C@@H](O)[C@H]2O)n1</smiles>

82a $\quad X=O \quad$ Ribavirin

82b $\quad X=\mathrm{NH}$ Taribavirin

$82 a, b$

Al-Soud et al. ${ }^{132}$ synthesized a new series of 1,2,4-triazole derivative to be tested against HIV. All the prepared compounds were inactive except $\mathbf{8 3}$ which showed activity against HIV.

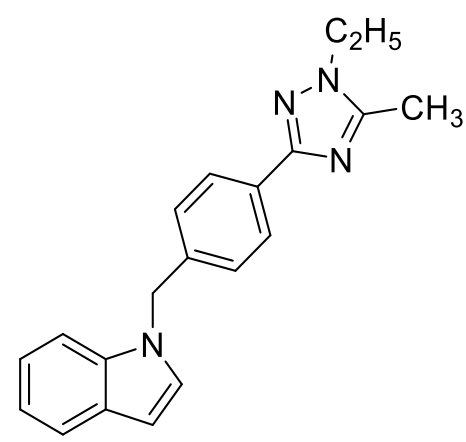

83

Pomarnacka and Kedra ${ }^{133}$ synthesized 1,2,4-triazolone derivatives $84 a-c$ which proved to have moderate anti-HIV activity. ${ }^{134}$ 


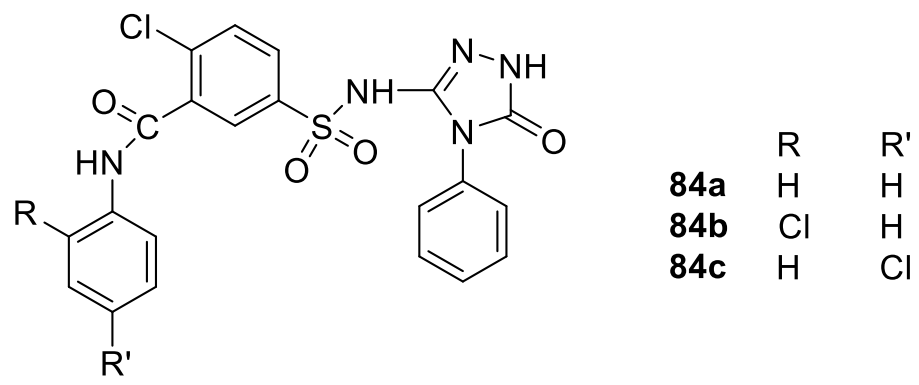

84a-c

Compound $\mathbf{8 5}$ is a pharmaceutical compound that can be used as an antivirus as well as inhibiting the growth of tumors and cancers in mammals. ${ }^{135}$<smiles>CC(C)C1COC(Cn2cncn2)(c2ccc(Cl)cc2Cl)O1</smiles>

85

Al-Soud and Al-Masoudi synthesized 1-[(1,5-disubstituted)-1H-1,2,4-triazol-3-yl)methyl]thymines 86a,b for their antiviral evaluation. These compounds showed moderate activity against HIV-1 (IIIB-strain), HIV-2 (rod strain) and CMV. ${ }^{136}$

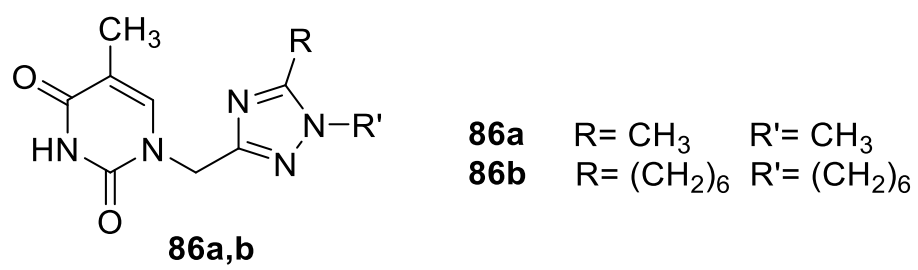

The compounds $\mathbf{8 7 a - c}$ and their $\mathrm{N}$-glycosides were synthesized and examined for antiviral action against RNA-3 poliomyelitis. ${ }^{137}$<smiles>[R]c1nc(SC)n[nH]1</smiles>

$87 a-c$

$\mathrm{R}=\mathrm{H}, \mathrm{Me}$, or Et and $\mathrm{R}^{1}=\mathrm{H}$

The triazole compound $\mathbf{8 8}$ inhibited bacteriophages on an Escherichia coli culture as well as decreasing the growth of tobacco mosaic virus in infected tobacco leaves. ${ }^{138}$ 


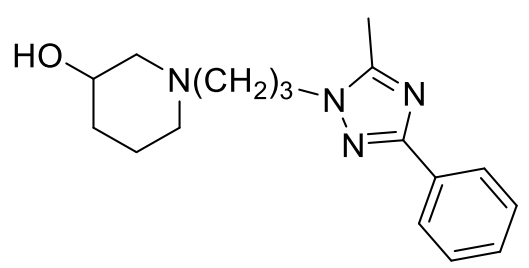

88

The cyanotriazole nucleoside analogue $89 a$ was able to reduce the Dengue virus replication at a concentration lower than that of ribavirin. This compound represents a promising drug candidate for the treatment of infections caused by a flavivirus. On the other hand, the D-ribofuranosyl-1,2,4-triazole-3carboxamide (89b) was found to be highly active against measles virus. ${ }^{139}$

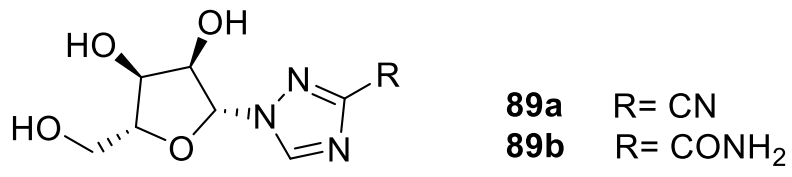

89 a,b

\section{Thiazole-containing Compounds as Antiviral Agents}

M. Abdalla et al. ${ }^{140}$ synthesized a series of new thiazoles 90 a-e that exhibited strong to moderate antiviral activity against rabies virus with 90 e the most active one.

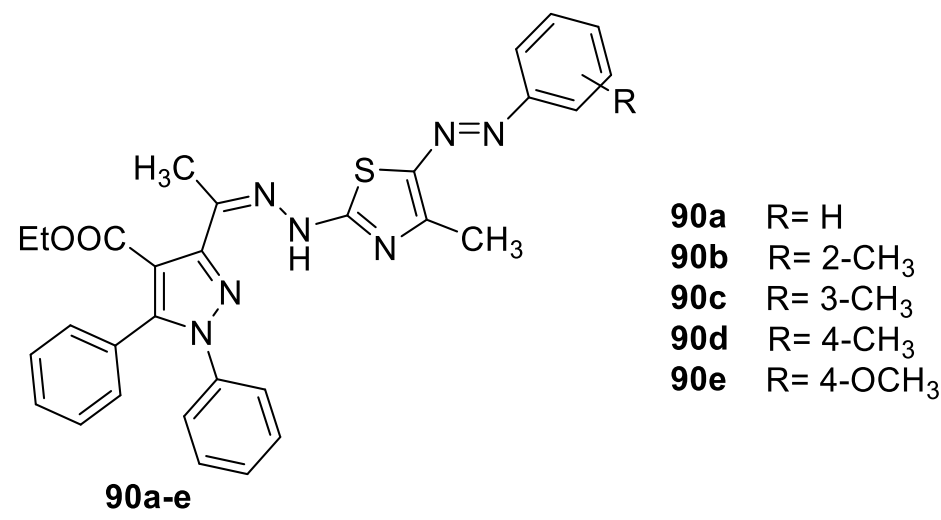

Faldaprevir (91) is another experimentally tested agent in phase III trials containing thiazole ring for treatment of HCV infections through inhibition of NS3-NS4A protease enzyme. ${ }^{141}$ 


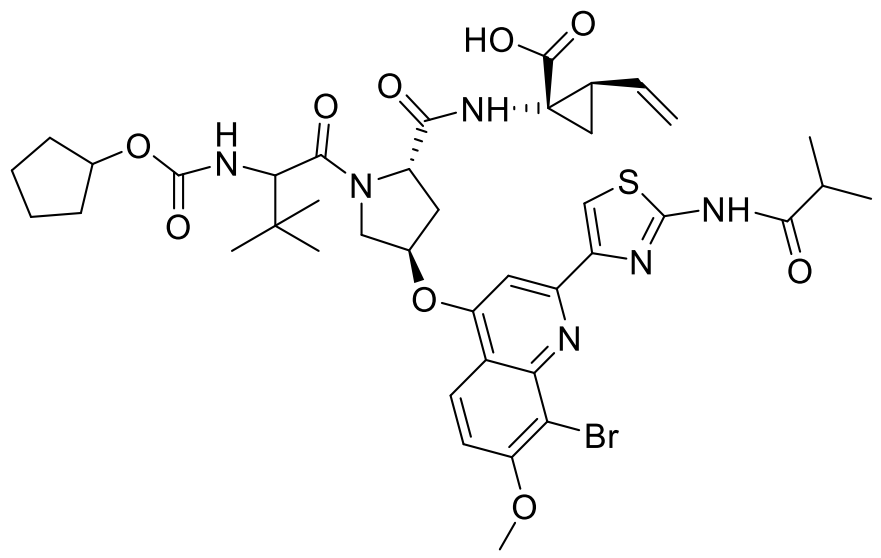

91

Dawood et al. ${ }^{142}$ synthesized a new series of thiazole derivatives 92 a-d that exhibited potent antiviral activity against $\mathrm{HCV}$.

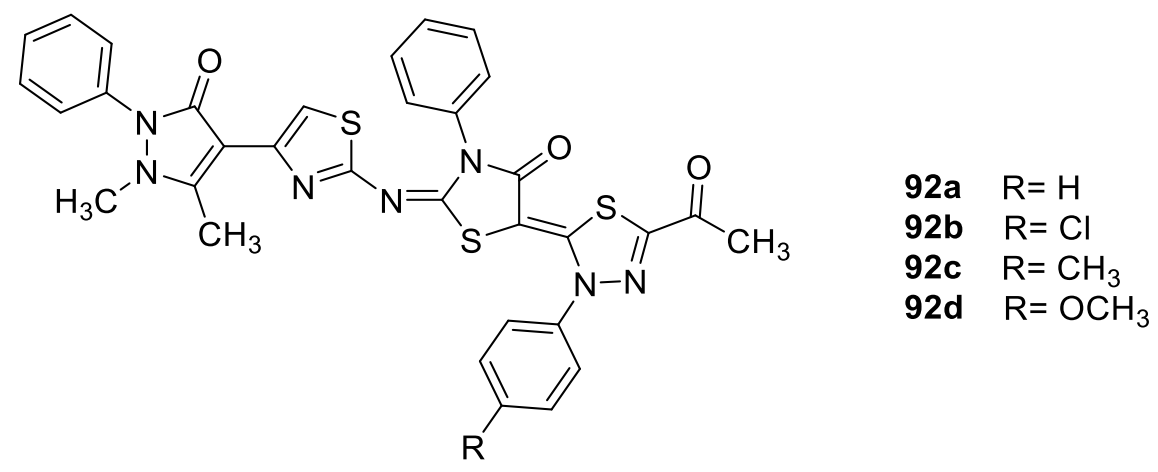

92a-d

Cobicistat (93) marketed as Tybost is a licensed drug, approved in 2015 and produced by Bristol-Myers Squibb for treatment of HIV-1 infections as a part of a combination therapy. ${ }^{143}$

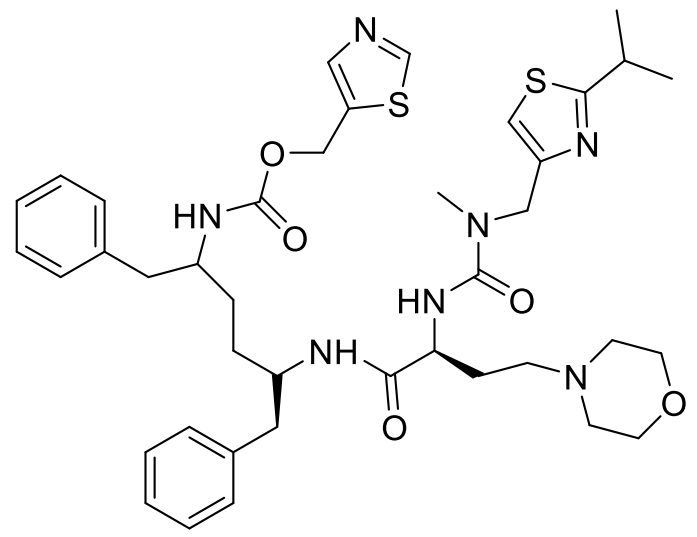

93

Simeprevir (94) marketed as Olysio or Sovriad is considered as HCV-protease inhibitor agent, used in combination with interferon- $\alpha$ and ribavirin. It was first developed by Medivir and Johnson \& Johnson's Pharmaceuticals. ${ }^{144}$ 


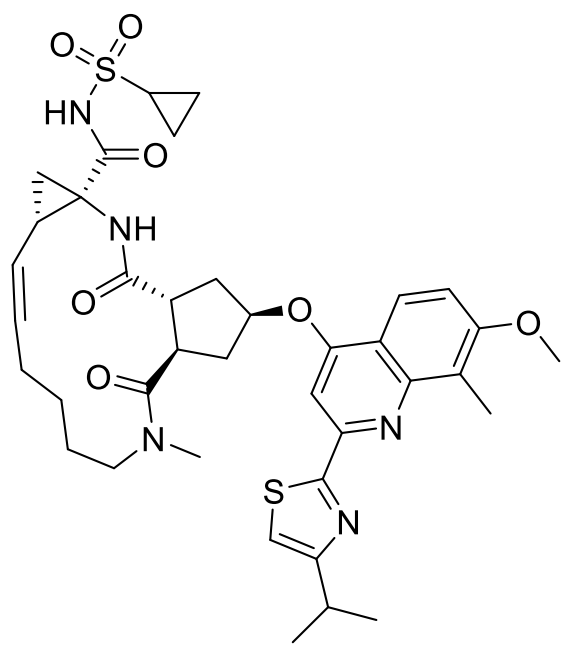

94

Brecanavir (95) code-named GW640385, HIV-protease inhibitor, but in 2006 GlaxoSmithKline stopped the drug development for problems in the formulation; they were unable to develop a viable oral dosage form that can achieve the drug levels required to treat multi-drug resistant HIV. ${ }^{145}$

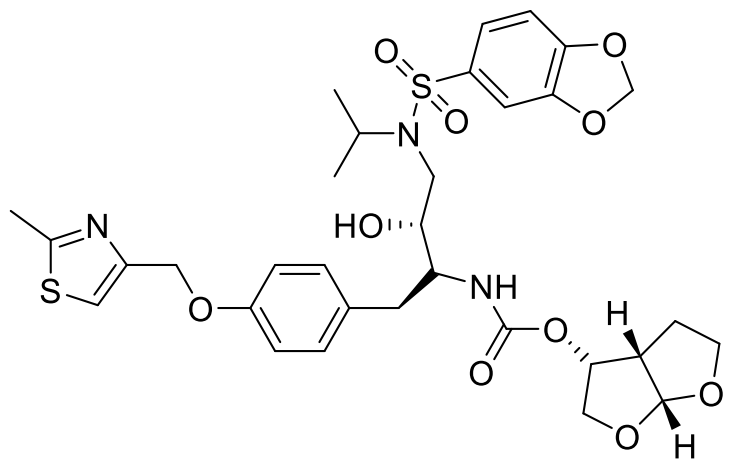

95

Compound $\mathbf{9 6}$ was synthesized and found to have excellent anti-HSV activity, that it can be considered as a lead for further development of antiviral agents. ${ }^{146}$

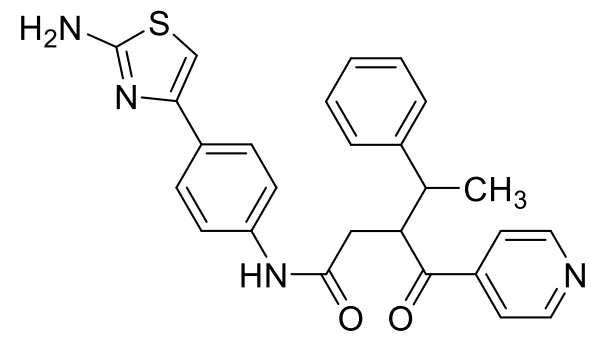

96

Ritonavir (97) marketed as Norvir, was first used in 1996 for treatment of retroviral infections and in combination with other medications for the treatment of hepatitis C infections. ${ }^{147}$ 


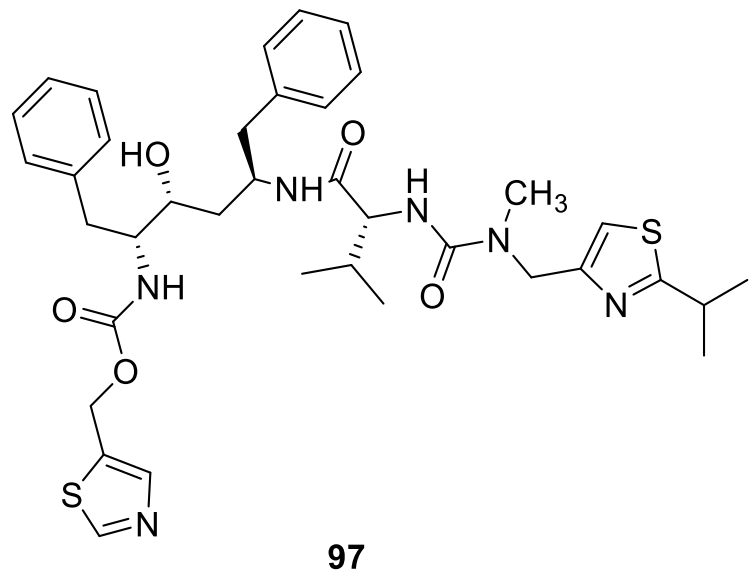

\section{References}

1. Goscienski P. J. Pediatr. Infect. Dis. 1983, 2, 69-81.

https://doi.org/10.1097/00006454-198301000-00018

2. Schoeman D.; Fielding B. C. Virol. J. 2019, 16, 69.

https://doi.org/10.1186/s12985-019-1182-0

3. Suzuki, A. Y.; Oshitani, H. Virol. 2010, 7, 52-55.

https://doi.org/10.1186/1743-422X-7-52

4. Henderson, D. A.; Inglesby, T. V.; Bartlett, J. G.; Ascher, M. S.; Eitzen, E.; Jahrling, P. B.; Hauer, J.; Layton, M.; McDade J.; Osterholm M. T.; Toole T.; Parker G.; Perl T.; Russell P. K.; Tonat K. JAMA 1999, 281, 2127-37.

https://doi.org/10.1001/jama.281.22.2127

5. Gagnon, A.; Miller, M. S.; Hallman, S. A.; Bourbeau, R.; Herring, D. A.; Earn, D. J.; Madrenas J. PLOS ONE 2013, 8, e69586.

https://doi.org/10.1371/journal.pone.0069586

6. Chen, Z.; Wang, N.; Huang, Y.; Wang, M. Exp. Ther. Med. 2019, 18, 523-530.

7. Kourtis, A. P.; Appelgren, K.; Chevalier, M. S.; McElroy A. Pediatr. Infect. Dis. J. 2015, 34, 893-897. https://doi.org/10.1097/INF.0000000000000707

8. Maurice, R.; Hilleman, D. S. Seminars in Pediatr. Infect. Dis. J. 2005, 16, 225-226. https://doi.org/10.1053/j.spid.2005.05.002

9. Verma, R.; Khanna, P.; Chawla, S. Hum. Vaccin. Immunother. 2014, 10, 126-128. https://doi.org/10.4161/hv.26549

10. Belongia, E. A.; Naleway, A. L. Clin. Med. Res. 2003, 1, 87-92. https://doi.org/10.3121/cmr.1.2.87

11. Sarafianos, S. G.; Marchand, B.; Das, K.; Himmel, D. M.; Parniak, M. A.;Hughes, S. H.; Arnold, E. J. Mol. Biol. 2009, 385, 693-713. https://doi.org/10.1016/i.jmb.2008.10.071

12. Wang, Q. Y.; Bushell, S.; Qing, M.; Xu, H. Y.; Bonavia, A.; Nunes, S.; Zhou, J.; Poh, M. K.; de Sessions, P. F.; Niyomrattanakit, P.; Dong, H. J. Virol. 2011, 85, 6548-6556. https://doi.org/10.1128/JVI.02510-10

13. Kempegowda, G. P.; Kumar, S.; Prakash, D.; Mani, T. Pharma Chem. 2011, 3, 330-341. 
14. Colanceska-Ragenovic, K.; Dimova, V.; Kakurinov, V.; Molnar, D. G.; Buzarovska, A. Molecules 2001, 6, 815-824.

https://doi.org/10.3390/61000815

15. Azza, R. M.; Abdelbasset, A. F.; Khalid, B. S.; Hassan, M. E. Med. Chem. Res. 2012, 21, 703-710. https://doi.org/10.1007/s00044-011-9574-8

16. Hassan, M. E.; Alaa-Eldin, M. B.; Sahar, M. B.; Abdelbasset, A. F. Ind. J. Chem. Section B. 2010, 49, 15151525.

17. Shaimaa, A. M.; Abdelbasset A. F.; Magda, N. A. N.; Atif S. T. Saudi Pharm. J. 2017, 25, 873-883. https://doi.org/10.1016/j.jsps.2017.02.003

18. Danuta, B.; Abdelbasset, A. F.; Tanja, W.; Reto, B.; Yang Liu, W.; David, W.; David, W. B. Bioorg. Med. Chem. 2010, 18, 3551-3558.

19. Almasirad, A.; Tabatabai, S. A.; Faizi, M.; Kebriaeezadeh, A.; Mehrabi, N.; Dalvandi, A.; Shafiee, A. Bioorg. Med. Chem. Lett. 2004, 14, 6057-6059.

https://doi.org/10.1016/j.bmcl.2004.09.072

20. Kaur, R.; Ranjan Dwivedi, A.; Kumar, B.; Kumar, V. Anti-Cancer Agent Me. 2016, 16, 465-489. https://doi.org/10.2174/1871520615666150819121106

21. Kattimani, P. P.; Kamble, R. R.; Kariduraganavar, M. Y.; Dorababu, A.; Hunnur, R. K. Eur. J. Med. Chem. 2013. 62, 232-240.

https://doi.org/10.1016/j.ejmech.2013.01.004

22. Almasirad, A.; Mousavi, Z.; Tajik, M.; Assarzadeh, M. J.; Shafiee, A. DARU 2014. 22, 22. https://doi.org/10.1186/2008-2231-22-22

23. Barbuceanu, S. F.; Ilies, D. C.; Saramet, G.; Uivarosi, V.; Draghici, C.; Radulescu, V. Int. J. Mol. Sci. 2014, 15, 10908-10925.

https://doi.org/10.3390/ijms150610908

24. Abdel-Fattah, H. A.; El-Etrawy, A. S.; Gabr, N. R. M. Int. J. Pharm. Chem. 2014, 4, 112-118.

25. Li, Y. H.; Zhang, B.; Yang, H. K.; Li, Q.; Diao, P. C.; You, W. W.; Zhao, P. L. Eur. J. Med. Chem. 2017, 125, 1098-1106.

https://doi.org/10.1016/j.ejmech.2016.10.051

26. Sonawane, A. D.; Rode, N. D.; Nawale, L.; Joshi, R. R.; Joshi, R. A.; Likhite, A. P.; Sarkar, D. Chem. Biol. Drug Des. 2017. 90, 200-209.

https://doi.org/10.1111/cbdd.12939

27. Holla, B. S.; Poojary, K. N.; Rao, B. S.; Shivananda, M. K. Eur. J. Med. Chem. 2002, 37, 511-517. https://doi.org/10.1016/S0223-5234(02)01358-2

28. Srestha, N.; Banerjee, J.; Srivastava, S. IOSR J. Pharma. 2014, 4, 28-41. https://doi.org/10.9790/3013-0401201028041

29. Ateş, O.; Kocabalkanli, A.; Saniş, G. O.; Ekinci, A. C.; Vidin, A. Arzneimittel-Forschung 1997, 47, 11341138.

30. Padmavathi, V.; Mahesh, K.; Nagendra Mohan, A. V.; Padmaja, A. Chem. Pharma. Bull. 2009, 57, 561566. https://doi.org/10.1248/cpb.57.561

31. Fan, Z.; Yang, Z.; Zhang, H.; Mi, N.; Wang, H.; Cai, F.; Zuo, X.; Zheng, Q.; Song, H. J. Agric. Food Chem. 2009. 58, 2630-2636.

32. Zuo, X.; Mi, N.; Fan, Z.; Zheng, Q.; Zhang, H.; Wang, H.; Yang, Z. J. Agric. Food Chem. 2009, 58, $2755-2762$. 
https://doi.org/10.1021/jf902863z

33. Tripathy, R.; Ghose, A.; Singh, J.; Bacon, E. R.; Angeles, T. S.; Yang, S. X.; Albom, M. S.; Aimone, L. D.; Herman, J. L.; Mallamo, J. P. Bioorg. Med. Chem. Lett. 2007, 17, 1793-1798. https://doi.org/10.1016/j.bmcl.2006.12.054

34. Fadda, A. A.; Abdel-Rahman, A. H.; El-Sayed, W. A.; Zidan, T. A.; Badria, F.A. Chem. Heterocycl. Compds 2011, 47, 856-864.

https://doi.org/10.1007/s10593-011-0847-4

35. Naik, R. N.; Patil, S. C.; Satyanarayan, S. B. Indo. Am. J. Pharm. 2014, 4, 3763-3772.

36. De Clercq, E.; Field, H. J. Br. J. Pharmacol. 2006, 147, 1-11.

https://doi.org/10.1038/sj.bjp.0706446

37. Johns, B. A.; Weatherhead, J. G.; Allen, S. H.; Thompson, J. B.; Garvey, E. P.; Foster, S. A.; Jeffrey, J. L.; Miller, W. H.; Bioorg. Med. Chem. Lett. 2009, 19, 1802-1806.

https://doi.org/10.1016/j.bmcl.2009.01.090

38. Dong, W.; Liu, Z.; Liu, X.; Li, Z.; Zhao, W. Eur. J. Med. Chem. 2010, 45, 1919-1926.

https://doi.org/10.1016/j.ejmech.2010.01.032

39. De Clercq, E. Biochim. Biophys. Acta. Mol. Basis Dis. 2002, 1587, 258-275.

https://doi.org/10.1016/S0925-4439(02)00089-3

40. El-Emam, A. A.; Al-Deeb, O. A.; Al-Omar, M.; Lehmann, J. Bioorg. Med. Chem. 2004, 12, 5107-5113. https://doi.org/10.1016/i.bmc.2004.07.033

41. Farghaly, A. R.; El-Kashef, H. Arkivoc 2006, (xi), 76-90. https://doi.org/10.3998/ark.5550190.0007.408

42. Cui, T.; Chum, M. P.; Lam, Y.; Gao, Y. Singapore Pat. Appl.SG 162629A1 20100729.2010.

43. Serban, G. Molecules 2020, 25, 942. https://doi.org/10.3390/molecules25040942

44. Brai, A.; Ronzini, S.; Riva, V.; Botta, L.; Zamperini, C.; Borgini, M.; Trivisani, C. I.; Garbelli, A.; Pennisi, C.; Boccuto, A. Molecules 2019, 24, 3988. https://doi.org/10.3390/molecules24213988

45. Tang, X.; Wang, Z.; Zhong, X.; Wang, X.; Chen, L.; He, M.; Xue, W. Phosphorus, Sulfur, Silicon Relat. Elem. 2019, 194, 241-248.

https://doi.org/10.1080/10426507.2018.1539992

46. Zhong, X.; Wang, X.; Chen, L.; Ruan, X.; Li, Q.; Zhang, J.; Chen, Z.; Xue, W. Chem. Cent. J. 2017, 11, 106. https://doi.org/10.1186/s13065-017-0336-7

47. Yu, L.; Gan, X.; Zhou, D.; He, F.; Zeng, S.; \& Hu, D. Molecules 2017, 22, 658. https://doi.org/10.3390/molecules22040658

48. Manvar, D.; Küçükgüzel, I.; Erensoy, G.; Tatar, E.; Deryabaşoğulları, G.; Reddy, H.; Kaushik-Basu, N. Biochem. Biophys. Res. Commun. 2016, 469, 743-747.

https://doi.org/10.1016/j.bbrc.2015.12.042

49. Wu, W.; Tai, A.; Chen, Q.; Ouyang, G. J. Heterocycl. Chem. 2016, 53, 626-632. https://doi.org/10.1002/jhet.2435

50. Dong, L.; Song, B.; Wu, J.; Wu, Z.; Zhu, Y.; Chen, X.; Hu, D. Phosphorus, Sulfur, Silicon Relat. Elem. 2016, 191, 904-907.

https://doi.org/10.1080/10426507.2015.1114944

51. Asif, M. Mediterr. J. Chem. 2016, 5, 568-588. 
https://doi.org/10.13171/mjc55/01606241121/asif

52. Kempegowda, G. P.; Kumar, S.; Prakash, D.; Mani, T. Der Pharma. Chem. 2011, 3, 330-341.

53. Tatar, E.; Kucukguzel, S. G.; Karakus, S.; Clercq, E. D.; Andrei, G.; Snoeck, R.; Pannecouque, C.; Oktem Okullu, S.; Unubol, N.; Kocagoz, T.; Kalayci, S. Marmara Pharm. J. 2015, 19, 88-102.

https://doi.org/10.12991/mpj.2015199639

54. Hussain, N.; Khan, S.; Ahmed, M.; Joshi, A.; Ashid, M.; Yogi, P. Chem. Bio. Interface 2015, 5, 365-377.

55. Fan, Z.; Fang, Z.; Wang, D.; Li, Y.; Ji, X.; Hua, X.; Mao, W.; Zong, G.; Li, F.; Li, J. 2014, CN 103641795 A 20140319

56. Hajimahdi, Z.; Zarghi, A.; Zabihollahi, R.; Aghasadeghi, M. R. Med. Chem. Res. 2013, 22, 2467-2475. https://doi.org/10.1007/s00044-012-0241-5

57. Gao, Y.; Samanta, S.; Cui, T.; Lam, Y. Chem. Med. Chem. 2013, 8, 1554-1560. https://doi.org/10.1002/cmdc.201300244

58. Xu, W.; Yang, S.; Xue, W.; Jin, L.; Chen, Z.; He, M.; Li, S.; Chen, Y. 2012, CN 102838593 A 20121226

59. Wang, S. X.; Fang, Z.; Fan, Z. J.; Wang, D.; Li, Y. D.; Ji, X. T.; Hua, X. W.; Huang, Y.; Kalinina, T. A.; Bakulev, V. A.; Morzherin, Y. Y. Chinese Chem. Lett. 2013, 24, 889-892.

https://doi.org/10.1016/j.cclet.2013.05.026

60. Chen, Z.; Xu, W.; Liu, K.; Yang, S.; Fan, H.; Bhadury, P. S.; Huang, D. Y.; Zhang, Y. Molecules 2010, 15, 9046-9056.

https://doi.org/10.3390/molecules15129046

61. Hamad, N. S.; Al-Haidery, N. H.; Al-Masoudi, I. A.; Sabri, M.; Sabri, L.; Al-Masoudi, N. A. Arch. Pharm. Chem. Life Sci. 2010, 343, 397-403.

https://doi.org/10.1002/ardp.200900293

62. Jain, A. K.; Sharma, S.; Vaidya, A.; Ravichandran, V. Agrawal, R. K. Chem. Biol. Drug Des. 2013, 81, 557576.

https://doi.org/10.1111/cbdd.12125

63. Thaisrivongs, S.; Turner, S. R. US Patent 6,150,385.2000.

64. Turner, S. R.; Thaisrivongs, S. PCT Int. Appl. WO 9947507 A2 19990923.1999

65. Parkanyi, C.; Yuan, H. L.; Stromberg, B. H.; Evenzahav, A. J. Heterocycl. Chem. 1992, 29, 749-753.

66. Paget Jr, C. J.; Rieder, B. J.; Spitzer, W. A.; Wu, C. Y. E. Eli Lilly. U.S. Patent 4,835,168.1989.

67. Orzalesi, Giovanni. Eur. Pat. Appl. 61434 A1 19820929.1982

68. Jones, D. H.; Slack, R.; Squires, S. T.; Wooldridge, K. R. H. J Med. Chem. 1965, 8, 676-680. https://doi.org/10.1021/jm00329a026

69. Li, Z.; Zhan, P.; Liu, X. Med. Chem. 2011. 11, 1130-1142. https://doi.org/10.2174/138955711797655407

70. Duarte, C. D.; Barreiro, E. J.; Fraga, C. A. Med. Chem. 2007, 7, 1108-1119. https://doi.org/10.2174/138955707782331722

71. Clercq, E. Curr. Med. Chem. 2001, 8, 1543-1572. https://doi.org/10.2174/0929867013371842

72. Aquino, C. J.; Dickson, H.; Peat, A. J. WO2008157330A1.2008.

73. Serrao, E.; Odde, S.; Ramkumar, K.; Neamati, N. Retrovirology 2009. 6, 25. https://doi.org/10.1186/1742-4690-6-25

74. Hamdani, S. S.; Khan, B. A.; Hameed, S.; Batool, F.; Saleem, H. N.; Ullah Mughal, E.; Saeed, M. Bioorg Chem. 2020, 96, 103567. 
https://doi.org/10.1016/j.bioorg.2020.103567

75. Kim, J.; Shin, J. A.; Han, S.; Jung, Y. ACS Med Chem. Lett. 2018, 9, 667-672.

https://doi.org/10.1021/acsmedchemlett.8b00134

76. Gan, X.; Hu, D.; Chen, Z.; Wang, Y.; Song, B. Bioorg. Med. Chem. Lett. 2017, 27, 4298-4301. https://doi.org/10.1016/j.bmcl.2017.08.038

77. Yu, L.; Wei, Y. CN 106928250 A 20170707.2017

78. Chudinov, M. V.; Zhurilo, N. I.; Matveev, A. V. Russ. 2017 RU 2629360 C1 20170829,

79. Wang, P.; Shao, W.; Xue, H.; Fang, H.; Zhou, J.; Wu, Z.; Song, B.; Yang, S. Res. Chem. Intermed. 2017, 43, 6115-6130.

https://doi.org/10.1007/s11164-017-2980-x

80. Gan, X. H.; Hu, D. Y.; Li, P. Pest Manag. Sci. 2016, 72, 534.

81. Chen, L.; Wang, P.; Li, Z.; Zhou, L.; Wu, Z.; Song, B.; Yang, S. Chinese J. Chem. 2016, 34, 1236-1244. https://doi.org/10.1002/cjoc.201600501

82. Zuo, W.; Wang, N.; Zhu, Y.; Liu, L.; Xiao, K.; Zhang, L.; Gao, C.; Liu, Z.; You, X.; Shi, Y. RSC Advances 2016, 6, 40277-40286.

https://doi.org/10.1039/C6RA01179A

83. Benmansour, F.; Eydoux, C.; Querat, G.; de Lamballerie, X.; Canard, B.; Alvarez, K.; Guillemot, J.; Barral, K. Eur. J. Med. Chem. 2016,109,146-156.

https://doi.org/10.1016/j.ejmech.2015.12.046

84. Musmade, D. S.; Pattan, S. R.; Yalgatti, M. S. Int. J. Pharm. Chem. 2015, 5, 11-20.

85. Iqbal, R.; Zareef, M.; Ahmed, S.; Zaidi, J. H.; Arfan, M.; Shafique, M.; Al-Masoudi, N. A. J. Chinese Chem. Soc-tap 2006, 53, 689-696.

https://doi.org/10.1002/jccs.200600091

86. Wu, W.; Chen, Q.; Tai, A.; Jiang, G.; Ouyang, G. Bioorg. Med. Chem. Lett. 2015, 25, 2243-2246. https://doi.org/10.1016/j.bmcl.2015.02.069

87. Yang, S.; Kuang, J.; Deng, H.; Xue, W.; Wu, Z.; Wu, S.; Zhang, T.; Chen, Y.; Zhou, Q.; Ye, Y. CN 103980223 A 20140813, 2014.

88. Burroughs, E. G.; Keicher, J. D.; You, S. PCT Int. Appl. WO 2013025858 A1 20130221, 2013.

89. Wang, Z.; Wang, M.; Yao, X.; Li, Y.; Qiao, W.; Geng, Y.; Wang, Q. Eur. J. Med. Chem. 2012, 50, 361-369. https://doi.org/10.1016/i.ejmech.2012.02.015

90. Di Francesco, M. E.; Avolio, S.; Pompei, M.; Pesci, S.; Monteagudo, E.; Pucci, V.; Giuliano, C.; Fiore, F.; Rowley, M.; Summa, V. Bioorg. Med. Chem. 2012, 20, 4801-4811.

https://doi.org/10.1016/j.bmc.2012.05.067

91. Syed, T.; Akhtar, T.; Al-Masoudi, N. A.; Jones, P. G.; Hameed, S. J. Enzyme Inhib. Med. Chem. 2011, 26, 668-680. https://doi.org/10.3109/14756366.2010.546792

92. El-Sayed, W. A.; El-Essawy, F. A.; Ali, O. M.; Nasr, B. S.; Abdalla, M. M.; Adel, A. H. Monatsh. Chem. 2010, 141, 1021-1028.

https://doi.org/10.1007/s00706-010-0360-y

93. Ravichandran, V.; Shalini, S.; Sundram, K.; Sokkalingam, A. Eur. J. Med. Chem. 2010, 45, 2791-2797. https://doi.org/10.1016/j.ejmech.2010.02.062

94. Johns, B. A.; Weatherhead, J. G.; Allen, S. H.; Thompson, J. B.; Garvey, E. P.; Foster, S. A.; Jeffrey, J. L.; Miller, W. H. Bioorg. Med. Chem. Lett. 2009, 19, 1807-1810. 


\section{https://doi.org/10.1016/j.bmcl.2009.01.089}

95. Di Francesco, M. E.; Dessole, G.; Nizi, E.; Pace, P.; Koch, U.; Fiore, F.; Pesci, S.; Di Muzio, J.; Monteagudo, E.; Rowley, M. Summa, V. J. Med. Chem. 2009, 52, 7014-7028.

https://doi.org/10.1021/jm900524b

96. Jorgensen, W. L. Acc. Chem. Res. 2009, 42, 724-733.

https://doi.org/10.1021/ar800236t

97. Barreiro, G.; Kim, J. T.; Guimarães, C. R.; Bailey, C. M.; Domaoal, R. A.; Wang, L.; Anderson, K. S.;

Jorgensen, W. L. J. Med. Chem., 2007, 50, 5324-5329.

https://doi.org/10.1021/im070683u

98. El-Essawy, F. A.; El-Sayed, W. A.; El-Kafrawy, S. A.; Morshedy, A. S.; Abdel-Rahman, A.-H. Zeitschrift für Naturforschung C. 2008, 63, 667-674.

https://doi.org/10.1515/znc-2008-9-1010

99. Abdel-Aal, Mohammed T.; El-Sayed, Waled A.; El-Kosy, Salah M.; El-Ashry, El Sayed H. Arch. Pharm. 2008, 341, 307-313.

https://doi.org/10.1002/ardp.200700154

100. Cullen, M. D.; Deng, B. L.; Hartman, T. L.; Watson, K. M.; Buckheit, R. W.; Pannecouque, C.; De Clercq, E.; Cushman, M. J. Med. Chem. 2007, 50, 4854-4867.

https://doi.org/10.1021/im070382k

101. Zhu, C.; Wu, Y.; Zhang, Y.; Cao, Q. CN 1687060 A 20051026, 2005.

102. Tan, T. M. C.; Chen, Y.; Kong, K. H.; Bai, J.; Li, Y.; Lim, S. G.; Ang, T. H.; Lam, Y. Antivir. Res. 2006, 71, 7-14. https://doi.org/10.1016/j.antiviral.2006.02.007

103. Nagaraj, C. K.; Niranjan, M. S.; Kiran, S. Int. J. Pharm. Pharm. Sci. 2011, 3, 9-16.

104. Kim, R. M.; Rouse, E.A.; Chapman, K. T.; Schleif, W. A.; Olsen, D. B.; Stahlhut, M.; Rutkowski, C. A.; Emini, E. A.; Tata, J. R. Bioorg Med. Chem. Lett. 2004, 14, 4651-4654.

https://doi.org/10.1016/j.bmcl.2004.06.092

105. Rashad, A. E.; Shamroukh, A. H.; El-Sayed, A. H.; Micky, J. A.; Marsok, N. A.; Abdel, F. M. E. Pharma Chemica 2016, 8, 75-81.

106. Asif, M. Chemistry International 2015, 1, 71-80.

107. Bilotta, J. A.; Chen, Zhi; Ding, Qingjie; Erickson, Shawn David; Mertz, Eric; Weikert, Robert J. PCT Int. Appl. WO 2014114573 A1 20140731, 2014.

108. Bilotta, Joseph A.; Chen, Z.; Chin, E.; Ding, Q.; Erickson, S. D.; Gabriel, S. D.; Klumpp, K.; Ma, H.; Mertz, E.; Plancher, J.; PCT Int. Appl. WO 2014006066 A1 20140109, 2014.

109. Nettles, R. E.; Schürmann, D.; Zhu, L.; Stonier, M.; Huang, S. P.; Chang, I.; Chien, C.; Krystal, M.; WindRotolo, M.; Ray, N. ; Hanna, G. J. J. Infect. Dis. 2012, 206, 1002-1011.

https://doi.org/10.1093/infdis/jis432

110. Maarouf, A. R.; Farahat, A. A.; Selim, K. B.; Eisa, H. M. Med. Chem. Res. 2012, 21, 703-710. https://doi.org/10.1007/s00044-011-9574-8

111. Modzelewska-Banachiewicz, B.; Ucherek, M.; Zimecki, M.; Kutkowska, J.; Kaminska, T.; MorakMlodawska, B.; Paprocka, R.; Szulc, M.; Lewandowski, G.; Marciniak, J. Arch. Pharm. 2012, 345, 486-494. https://doi.org/10.1002/ardp.201100333

112. Benci, K.; Suhina, T.; Mandić, L.; Pavelić, S. K.; Paravić, A. T.; Pavelić, K.; Balzarini, J.; Wittine, K. ; Mintas, M. Antivir. Chem. Chemother. 2011, 21, 221-230.

https://doi.org/10.3851/IMP1762 
113. Shneine J. K.; Alaraja Y. H. Int. J. Sci. Res. 2016. 5, 1411-1423.

114. Kumar H.; Neena, J. Chem. Sci., 2010. 1, 1-19.

115. McDowell, M.; Gonzales, S. R.; Kumarapperuma, S. C.; Jeselnik, M.; Arterburn, J. B.; Hanley, K. A. Antivir. Res. 2010, 87, 78-80.

https://doi.org/10.1016/j.antiviral.2010.04.007

116. Chung, D.-H.; Kumarapperuma, S. C.; Sun, Y.; Li, Q.; Chu, Y.-K.; Arterburn, J. B.; Jonsson, C. B. Antivir. Res. 2008, 79, 19-27.

https://doi.org/10.1016/j.antiviral.2008.02.003

117. Levy, J. A. Aids 2009, 23, 147-160.

https://doi.org/10.1097/QAD.0b013e3283217f9f

118. Zhou, C.; Gan, L.; Zhang, Y.; Zhang, F.; Wang, G.; Jin, L.; Geng, R. Chemistry 2009, 52, 415-458. https://doi.org/10.1007/s11426-009-0103-2

119. Liu, Z.; Zhu, Q.; Li, F.; Zhang, L.; Leng, Y.; Zhang, A. Med. Chem. Comm. 2011, 2, 531-535. https://doi.org/10.1039/c1md00002k

120. Johns, B. A.; Weatherhead, J. G.; Allen, S. H.; Thompson, J. B.; Garvey, E. P.; Foster, S. A.; Jeffrey, J. L.; Miller, W. H. Bioorg. Med. Chem. Lett. 2009, 19, 1807-1810.

https://doi.org/10.1016/j.bmcl.2009.01.089

121. Kucukguzel, I.; Tatar, E.; Kucukguzel, S. G.; Rollas, S.; De Clercq, E. Eur. J. Med. Chem. 2008, 43, $381-392$. https://doi.org/10.1016/j.ejmech.2007.04.010

122. Zhu, R.; Wang, M.; Xia, Y.; Qu, F.; Neyts, J.; Peng, L. Bioorg. Med. Chem. Lett. 2008, 18, 3321-3327. https://doi.org/10.1016/j.bmcl.2008.04.026

123. Kirschberg, T. A.; Balakrishnan, M.; Huang, W.; Hluhanich, R.; Kutty, N.; Liclican, A. C.; McColl, D. J.; Squires, N. H.; Lansdon, E. B. Bioorg. Med. Chem. Lett. 2008, 18, 1131-1134.

https://doi.org/10.1016/j.bmcl.2007.11.127

124. Vivet-Boudou, V.; Paillart, J. C.; Burger, A.; Marquet, R. Nucleos. Nucleot. Nucl. Acids 2007, 26, 743-746. https://doi.org/10.1080/15257770701490902

125. Kharb, R.; Shahar Yar, M.; Chander Sharma, P. Med. Chem. 2011, 11, 84-96. https://doi.org/10.2174/138955711793564051

126. Kumarapperuma, S. C.; Sun, Y.; Jeselnik, M.; Chung, K.; Parker, W. B.; Jonsson, C. B.; Arterburn, J. B. Bioorg. Med. Chem. Lett. 2007, 17, 3203-3207. https://doi.org/10.1016/i.bmcl.2007.03.018

127. Wang, Z.; Wu, B.; Kuhen, K. L.; Bursulaya, B.; Nguyen, T. N.; Nguyen, D. G.; He, Y. Bioorg. Med. Chem. Lett. 2006, 16, 4174-4177. https://doi.org/10.1016/j.bmcl.2006.05.096

128. Kharb, R.; Sharma, P. C.; Yar, M. S. J. Enzyme Inhib. Med. Chem. 2011. 26, 1-21. https://doi.org/10.3109/14756360903524304

129. De La Rosa, M.; Kim, H. W.; Gunic, E.; Jenket, C.; Boyle, U.; Koh, Y. H.; Korboukh, I.; Allan, M.; Zhang, W.; Chen, H.; Xu, W. Bioorg. Med. Chem. Lett. 2006, 16, 4444-4449. https://doi.org/10.1016/j.bmcl.2006.06.048

130. Sidwell, R. W.; Huffman, J. H.; Khare, L.; Allen, B.; Witkowski, R.; Robins, K. Science 1972, 177, 705-706. https://doi.org/10.1126/science.177.4050.705

131. Deming, P.; Arora, S. Expert Opin. Investig. Drugs 2011, 20, 1435-1443. https://doi.org/10.1517/13543784.2011.606214 
132. Al-Soud, Y. A.; Al-Dweri, M. N.; Al-Masoudi, N. A. II Farmaco 2004, 59, 775-783.

https://doi.org/10.1016/j.farmac.2004.05.006

133. Pomarnacka, E.; Kozlarska-Kedra, II Farmaco 2003, 58, 423-429.

134. Singh, G.; Sharma, P.; Dadhwal, S.; Garg, P.; Sharma, S.; Mahajan, N.; Rawal, S. Int. J. Curr. Pharm. Res. 2011, 3, 105-118.

135. Camden, James Berger. U.S. Pat. Appl. Publ. 2001, US 20010039291 A1 20011108

136. Al-Soud, Y. A.; Al-Masoudi, N. A. Arch. Pharm. 1999. 332, 143-144. https://doi.org/10.1002/(SICI)1521-4184(19994)332:4<143::AID-ARDP143>3.0.CO;2-C

137. Ertan, M.; Ersan, S. Ankara Universitesi Eczacilik Fakultesi Dergisi 1984, 14, 81-93.

138. Menzel, G.; Kluge, S. From Zentralblatt für Bakteriologie, Parasitenkunde, Infektionskrankheiten und Hygiene, Abteilung 2, Naturwissenschaftliche: Mikrobiologie der Landwirtschaft, der Technologie und des Umweltschutzes 1979, 134, 624-6. https://doi.org/10.1016/S0323-6056(79)80113-5

139. Streeter, D. G.; Witkowski, J. T.; Khare, G. P.; Sidwell, R. W.; Bauer, R. J.; Robins, R. K.; Simon, L. N. PNAS 1973, 70, 1174-1178.

https://doi.org/10.1073/pnas.70.4.1174

140. Abdalla, M.; Gomha, S.; Elaziz, M. A.; Serag, N. Turk. J. Chem. 2016, 40, 441-453. https://doi.org/10.3906/kim-1506-13

141. Campagna, D.; Demma, S. Drugs today 2015. 51, 289-301. https://doi.org/10.1358/dot.2015.51.5.2321008

142. Dawood, K. M.; Eldebss, T. M.; El-Zahabi, H. S.; Yousef, M. H. Eur. J. Med. Chem. 2015, 102, $266-276$. https://doi.org/10.1016/j.ejmech.2015.08.005

143. Lepist, E. I.; Phan, T. K.; Roy, A.; Tong, L.; MacLennan, K.; Murray, B.; Ray, A. S. Antimicrob. Agents Chemother. 2012, 56, 5409-5413. https://doi.org/10.1128/AAC.01089-12

144. Lin, T. I.; Lenz, O.; Fanning, G.; Verbinnen, T.; Delouvroy, F.; Scholliers, A.; Vermeiren, K.; Rosenquist, A.; Edlund, M.; Samuelsson, B.; Vrang, L. Antimicrob. Agents Chemother. 2009, 53, 1377-1385. https://doi.org/10.1128/AAC.01058-08

145. Hazen, R.; Harvey, R.; Ferris, R.; Craig, C.; Yates, P.; Griffin, P.; Miller, J.; Kaldor, I.; Ray, J.; Samano, V.; Furfine, E. Antimicrob. Agents Chemother. 2007, 51, 3147-3154.

https://doi.org/10.1128/AAC.00401-07

146. Crute, J. J.; Grygon, C. A.; Hargrave, K. D.; Simoneau, B.; Faucher, A. M.; Bolger, G.; Kibler, P.; Liuzzi, M.; Cordingley, M. G. Nat. Med. 2002, 8, 386-391. https://doi.org/10.1038/nm0402-386

147. Deeks, S. G.; Smith, M.; Holodniy, M.; Kahn, J. O. JAMA 1997, 277, 145-153. https://doi.org/10.1001/jama.1997.03540260059037 


\section{Authors' Biographies}

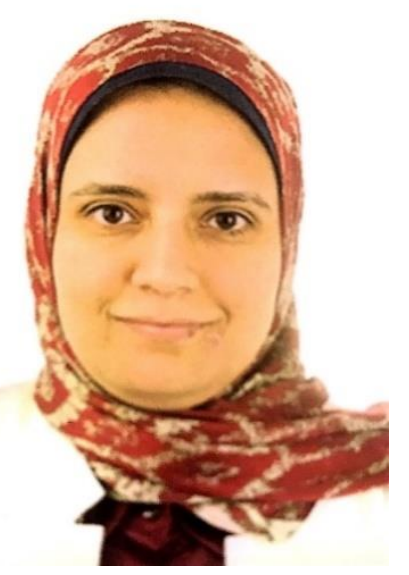

Samar Tawfik received a bachelor's degree in Pharmaceutical Science, at Mansoura University, Egypt, 2006, her Master's degree in Pharmaceutical Organic Chemistry, Mansoura University, 2012, and her Ph.D. in Pharmaceutical Organic Chemistry, Mansoura University, 2017, under the Supervision of Prof. Atef Tantawy. Dr. Samir is working now as an assistant professor of Pharmaceutical Organic Chemistry at Mansoura University. Dr. Samir is interested in the design and synthesis of new compounds to be investigated as antiviral agents, especially those acting as anti-influenza.

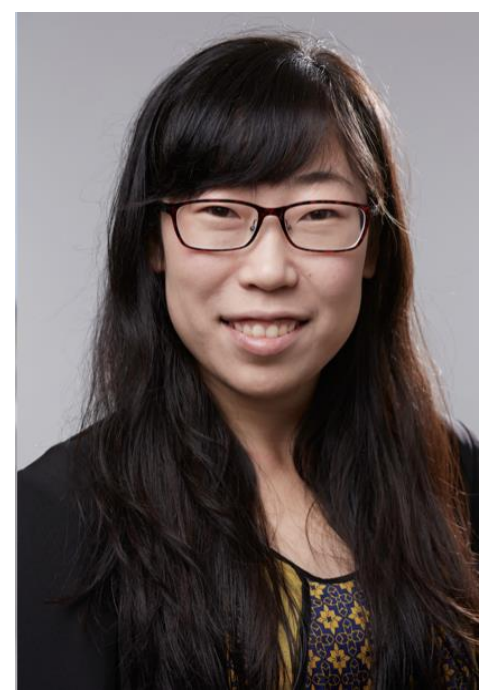

Mengyao Liu is a graduate of UC Berkeley majoring in Molecular Cell Biology B.S. She has been with the Feeley-Liu Lab for 3 years and specializes in tissue engineering, tissue culture, and genetic analysis. She runs the basic science and cell culture group and serves as a mentor for the junior investigators in the lab. Currently, she is in her second year of MPS program at California Northstate University. 


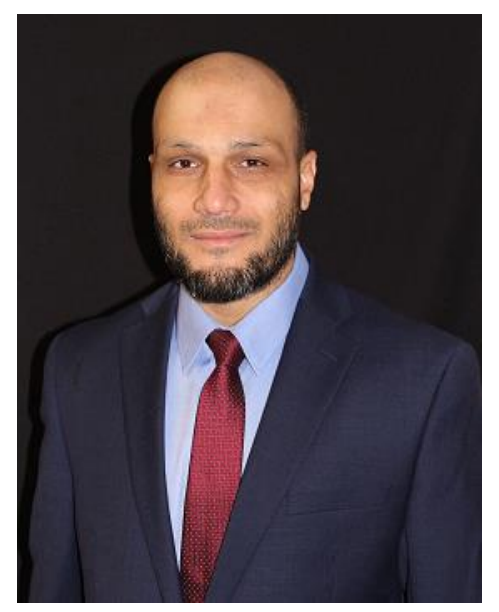

Abdelbasset Farahat is an Assistant Professor of Pharmaceutical and Medicinal Chemistry in the Department of Pharmaceutical and Biomedical Sciences, Master of Pharmaceutical Sciences at California Northstate University. In 2002, Dr. Farahat received a Bachelor of Pharmacy from Mansoura University Egypt, and then in 2006, he received a Master of Pharmaceutical Sciences from Mansoura University. In 2010 Dr. Farahat received his Ph.D. in Medicinal Chemistry after research at Georgia State University, Atlanta, GA, USA under the supervision of Prof. David W. Boykin. His Ph.D. research focused on the design and synthesis of dicationic compounds to be used as antimalarial and antitrypanosomal agents. In 2011, Dr. Farahat joined the Faculty of Pharmacy, Mansoura University as Assistant Professor. In 2012 he joined Boykin's laboratory at Georgia State University, Atlanta, GA as a Postdoctoral researcher, then research scientist and team leader. In 2018 Dr. Farahat joined Kennesaw State University as Assistant Professor of Medicinal Chemistry. In 2018 Dr. Farahat was awarded The Encouragement State Prize in Medical Sciences from the Academy of Scientific Research and Technology, Egypt. Dr. Farahat has published 69 publications in high impact peer-reviewed journals and is an inventor of three patents.

Dr. Farahat's research focuses on medicinal chemistry and synthetic organic chemistry projects. The focus is primarily on targeting the DNA minor-groove as an approach for antiparasitic drug discovery. This work is mostly directed towards the discovery of antimalarial, antitrypanosomal, antileishmanial, antinaeglerial and antiacanthamoebal drugs. More recently his research has turned to developing heterocyclic dications for DNA minor groove binding which induce topological effects, binding into either the major or minor grooves in specific parasitic sequences to generate a new mode of therapeutic activity.

This paper is an open access article distributed under the terms of the Creative Commons Attribution (CC BY) license (http://creativecommons.org/licenses/by/4.0/) 